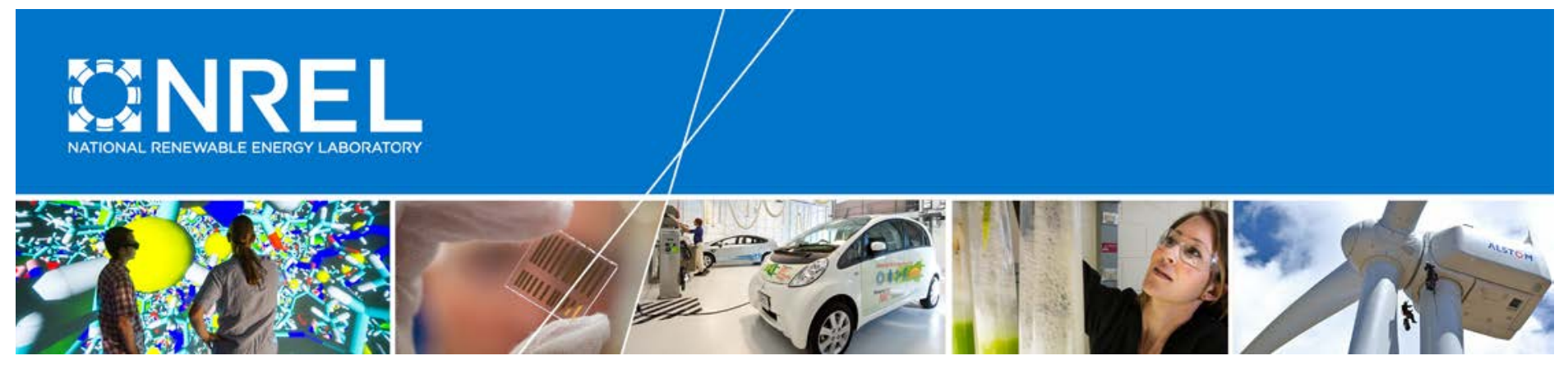

\title{
Compensation for Distributed Solar: A Survey of Options to Preserve Stakeholder Value
}

Francisco Flores-Espino National Renewable Energy Laboratory

NREL is a national laboratory of the U.S. Department of Energy Office of Energy Efficiency \& Renewable Energy Operated by the Alliance for Sustainable Energy, LLC

This report is available at no cost from the National Renewable Energy Laboratory (NREL) at www.nrel.gov/publications.

Technical Report

NREL/TP-6A20-62371

September 2015 


\section{Compensation for Distributed Solar: A Survey of Options to Preserve Stakeholder Value}

\author{
Francisco Flores-Espino \\ National Renewable Energy Laboratory
}

Prepared under Task No. SM13.1560
National Renewable Energy Laboratory 15013 Denver West Parkway Golden, CO 80401

303-275-3000 • www.nrel.gov
NREL is a national laboratory of the U.S. Department of Energy Office of Energy Efficiency \& Renewable Energy Operated by the Alliance for Sustainable Energy, LLC

This report is available at no cost from the National Renewable Energy Laboratory (NREL) at www.nrel.gov/publications.

\section{Technical Report}

NREL/TP-6A20-62371

September 2015

Contract No. DE-AC36-08GO28308 


\title{
NOTICE
}

This report was prepared as an account of work sponsored by an agency of the United States government. Neither the United States government nor any agency thereof, nor any of their employees, makes any warranty, express or implied, or assumes any legal liability or responsibility for the accuracy, completeness, or usefulness of any information, apparatus, product, or process disclosed, or represents that its use would not infringe privately owned rights. Reference herein to any specific commercial product, process, or service by trade name, trademark, manufacturer, or otherwise does not necessarily constitute or imply its endorsement, recommendation, or favoring by the United States government or any agency thereof. The views and opinions of authors expressed herein do not necessarily state or reflect those of the United States government or any agency thereof.

This report is available at no cost from the National Renewable Energy Laboratory (NREL) at www.nrel.gov/publications.

Available electronically at SciTech Connect http:/www.osti.gov/scitech

Available for a processing fee to U.S. Department of Energy and its contractors, in paper, from:

\author{
U.S. Department of Energy \\ Office of Scientific and Technical Information \\ P.O. Box 62 \\ Oak Ridge, TN 37831-0062 \\ OSTI http://www.osti.gov \\ Phone: 865.576.8401 \\ Fax: 865.576.5728 \\ Email: reports@osti.gov
}

Available for sale to the public, in paper, from:

\author{
U.S. Department of Commerce \\ National Technical Information Service \\ 5301 Shawnee Road \\ Alexandria, VA 22312 \\ NTIS http://www.ntis.gov \\ Phone: 800.553 .6847 or 703.605 .6000 \\ Fax: 703.605.6900 \\ Email: orders@ntis.gov
}




\section{Acknowledgments}

This report provides a framework of mechanisms that address compensation for PV owners, alternative retail rate design, and utility value preservation. A complementary report, Impact of Rate Design Alternatives on Residential Solar Customer Bills: Increased Fixed Charges, Minimum Bills and Demand-Based Rates, presents data and modeling results to examine impacts of rate design alternatives on customer electricity bills. Together, these NREL reports address some of the issues at the intersection of utility policy and compensation mechanisms for distributed generation customers.

The author wishes to thank the U.S. Department of Energy's (DOE's) Solar Energy Technologies Office for the sponsorship and guidance on this work. I also appreciate the critical reviews by the following individuals, which greatly improved and informed the analysis contained herein:

- Glen Andersen, National Conference of State Legislators

- Lori Bird, National Renewable Energy Laboratory (NREL)

- David L. Brown, Sacramento Municipal Utility District

- Matthew J. Croucher, CPS Energy

- Ted Davidovich, Solar Electric Power Association

- Rusty Haynes, EQ Research

- Jenny Heeter, NREL

- Heather Lammers, NREL

- Warren Leon, Clean Energy States Alliance

- Jeff Logan, NREL

- Joyce McLaren, NREL

- David Mooney, NREL

- Robin Newmark, NREL

- Gian Porro, NREL

- Ammar Qusaibaty, U.S. Department of Energy

- Eric Rogers, We Energies

- Chase Sun, Pacific Gas and Electric Company (PG\&E)

- Mary Werner, NREL.

These reviewers may have different views on one or more matters addressed in the report. They were not asked individually or collectively to endorse the report findings nor should any implied endorsement by the reviewers be assumed. 


\section{List of Acronyms}

\section{ACEEE}

APS

ASU-EPIC

CHP

CPUC

$\mathrm{CO}_{2}$

CUNY

DG

DLMP

DOE

DSIRE

EIA

GHG

GW

IEA

IREC

IRS

ITC

$\mathrm{kW}$

$\mathrm{kWh}$

LBNL

LRAM

MW

NEM

NPV

NREL

O\&M

PURPA

PV

RAP

REC

REV

RMI

ROE

RPC

RPS

SB

SEPA

SREC

TOU

TRC

VOS
American Council for an Energy-Efficient Economy

Arizona Public Service

Arizona State University - Energy Policy

Innovation Council

Combined heat and power

California Public Utilities Commission

carbon dioxide

The City University of New York

distributed generation

distributed locational marginal price

U.S. Department of Energy

Database of State Incentives for Renewables \&

Efficiency

U.S. Energy Information Administration

greenhouse gas

gigawatt

International Energy Agency

Interstate Renewable Energy Council

Internal Revenue Service

investment tax credit

kilowatt

kilowatt-hour

Lawrence Berkeley National Laboratory

lost revenue adjustment mechanism

megawatt

net metering or net energy metering

net present value

National Renewable Energy Laboratory

operations and maintenance

Public Utility Regulatory Policies Act

photovoltaic

Regulatory Assistance Project

renewable energy credit

Reforming the Energy Vision (New York)

Rocky Mountain Institute

return on equity

revenue-per-customer (decoupling)

renewable portfolio standard

Senate bill

Solar Electric Power Association

solar renewable energy credit

time-of-use (rate)

total resource cost

value of solar 
VPSD

WPS

WPSC
Vermont Public Service Department

Wisconsin Public Service

Wisconsin Public Service Commission 


\section{Executive Summary}

Compensation mechanisms for electricity generation systems installed behind the meter are under scrutiny in several jurisdictions in the United States. Legislators in 29 states introduced bills to amend net metering provisions in 2014, and in 33 states in the 2015 legislative session as of August 20, 2015 (Haynes 2015). Some utilities have also sought to increase the revenue they receive from net-metered customers through rate redesign. The circumstances that have triggered the recent push for change include a growing percentage of net-metered customers, potential effects of distributed generation on cost allocation, decreasing photovoltaic (PV) system costs, the challenges of integrating high levels of solar generation in the distribution network, and increasing pressure on utility business models.

As the relevant stakeholders work to amend net metering policies to balance public and private interests, an understanding of recent trends and potential effects can be useful to assess risks and minimize the adverse effects of uncertainty. This study reviews current distributed generation compensation policies in the United States and summarizes the issues prompting states to revise those policies. It also examines the recent rate redesign proposals that affect DG compensation and quantifies the impact some of these proposed changes could have on the economics of distributed PV systems. Finally, this study presents DG compensation options that can be implemented - independently or in combination - to provide stakeholders with certainty and preserve stakeholder value. This study does not intend to be an exhaustive or in-depth review of all the distributed generation $(\mathrm{DG})^{1}$ compensation options available.

Net metering policies and DG compensation levels have remained fairly stable nationwide since their inception. The increased impetus to change the way PV customers ${ }^{2}$ are compensated represents a risk to the solar industry (Howland 2013). The ripple effects of regulatory uncertainty are difficult to measure and could include constraints to the expansion of the solar industry, higher costs of capital, and reduced investment. Additionally, abrupt changes to the way PV customers are compensated could negatively impact the solar industry and existing solar PV owners.

Net metering credits distributed PV generation at retail rates. Owners of PV systems can generally carry their unused credits over to the next billing cycle. At the end of the net metering cycle, typically one year, the remaining credits are paid at wholesale rates by the utility, carried over, or forfeited, depending on state policy.

The proportion of total energy generated by distributed PV to total utility retail sales is less than $1 \%$ in most states and only three utilities in the United States buy back a proportion of generation from customer generators higher than $1 \%$ of their total retail sales (Table ES-1) (EIA 2015b).

\footnotetext{
${ }^{1}$ In this report, distributed generation refers to any customer-sited generation and distributed solar refers to customer-sited photovoltaics (PV) unless otherwise noted.

${ }^{2}$ PV customers produce $95 \%$ of customer-sited DG. This report centers on PV customers. However, most of the information in this report also applies to non-PV DG customers.
} 
Table ES-1. Utilities with Highest Proportion Of Energy Sold Back to Total Energy Sales

\begin{tabular}{|l|l|r|r|r|}
\hline Utility (State) & Type & $\begin{array}{l}\text { Total Retail } \\
\text { Sales (MWh) }\end{array}$ & $\begin{array}{l}\text { Energy Sold } \\
\text { Back (MWh) }\end{array}$ & \multicolumn{2}{l|}{$\begin{array}{l}\text { Sol Total } \\
\text { Sales }\end{array}$} \\
\hline Hawaii Electric Light Co., Inc. (HI) & Investor-Owned & $1,076,104$ & 21,060 & $2.0 \%$ \\
\hline Kauai Island Utility Cooperative (HI) & Cooperative & 431,478 & 7,177 & $1.7 \%$ \\
\hline NSTAR Electric Company (MA) & Investor-Owned & $8,521,681$ & 97,252 & $1.1 \%$ \\
\hline City of Alameda (CA) & Municipal & 363,444 & 3,395 & $0.9 \%$ \\
\hline Turlock Irrigation District (CA) & Public District & $1,975,891$ & 18,074 & $0.9 \%$ \\
\hline Tucson Electric Power Co. (AZ) & Investor-Owned & $9,278,919$ & 48,734 & $0.5 \%$ \\
\hline
\end{tabular}

Source: EIA 2015b, with data from $2013^{3}$

The extent to which net metering imposes costs on non-participants or the electric system as a whole is unclear. A number of studies have attempted to assess the costs and benefits of distributed PV. The results cannot be easily compared because each study takes a different perspective or looks at a different set of variables (RMI 2013; CPUC 2013; Stanton et al. 2014). Studies commissioned by state legislatures or regulatory commissions have generally found that net metering does not impose a significant cost to non-participants at current levels of penetration. However, the results are not uniform. For example, California found that netmetered systems impose a cost to all ratepayers, whereas Mississippi-among other statesfound net benefits statewide (CPUC 2013; Stanton et al. 2014).

The impacts of current DG compensation policies on the electricity system and utility business models will increase with DG penetration rates. A 2014 study by Lawrence Berkeley National Laboratory (LBNL) found that scenarios in which net-metered PV systems produced $2.5 \%$ of total retail sales and above could have negative effects on utilities' earnings and shareholder returns (Satchwell et al. 2014). As such, changes in DG compensation policies may eventually be considered to balance the interests of PV customers, utilities, the solar industry, and related stakeholders.

New rate designs have emerged since 2013 as a mechanism to address concerns regarding compensation for distributed generation. Electricity rate changes — proposed mainly by utilities - include increased fixed monthly charges, demand and standby charges assessed to residential customers or PV customers, and changes to the value PV customers receive for the energy they deliver to the grid. Rate design changes can have a dramatic effect on the value of distributed PV systems. For example, a proposal by Idaho Power filed in 2013 (Idaho Public Utilities Commission 2013) would have decreased residential PV customer savings by up to $65 \%$ in the first year. Owners of installed systems are especially vulnerable to rate and policy changes that do not exempt existing systems.

As circumstances - such as PV penetration levels and costs - change, adjusting DG compensation levels through deliberate and transparent mechanisms that balance the interests of all relevant stakeholders could help maximize benefits system-wide. Relevant stakeholders may include utilities, PV customers, non-PV customers, and policymakers.

\footnotetext{
${ }^{3}$ Net metering data is reported to EIA on a voluntary basis.
} 
A publicly discussed, transparent mechanism to implement major changes to rate design may reduce uncertainty and achieve fair solutions for the utilities, solar industry, and other players. A flexible mechanism may allow for the participation of all relevant stakeholders and take into account the particular conditions, such as DG penetration levels, of each jurisdiction.

This report presents a survey of options to charge and compensate PV customers, as well as options that may preserve utility revenues in scenarios with increased DG. These options could be used as building blocks to create a DG compensation policy that may preserve the value of the different stakeholders and balance their interests (Figure ES-1).

Preserving value has a different meaning depending on the perspective of each stakeholder. For utilities, it may mean retaining their ability to recover the costs of serving their customers and provide a return to their investors. For PV customers, preserving value may mean achieving a positive net present value for the economic life of their PV systems.

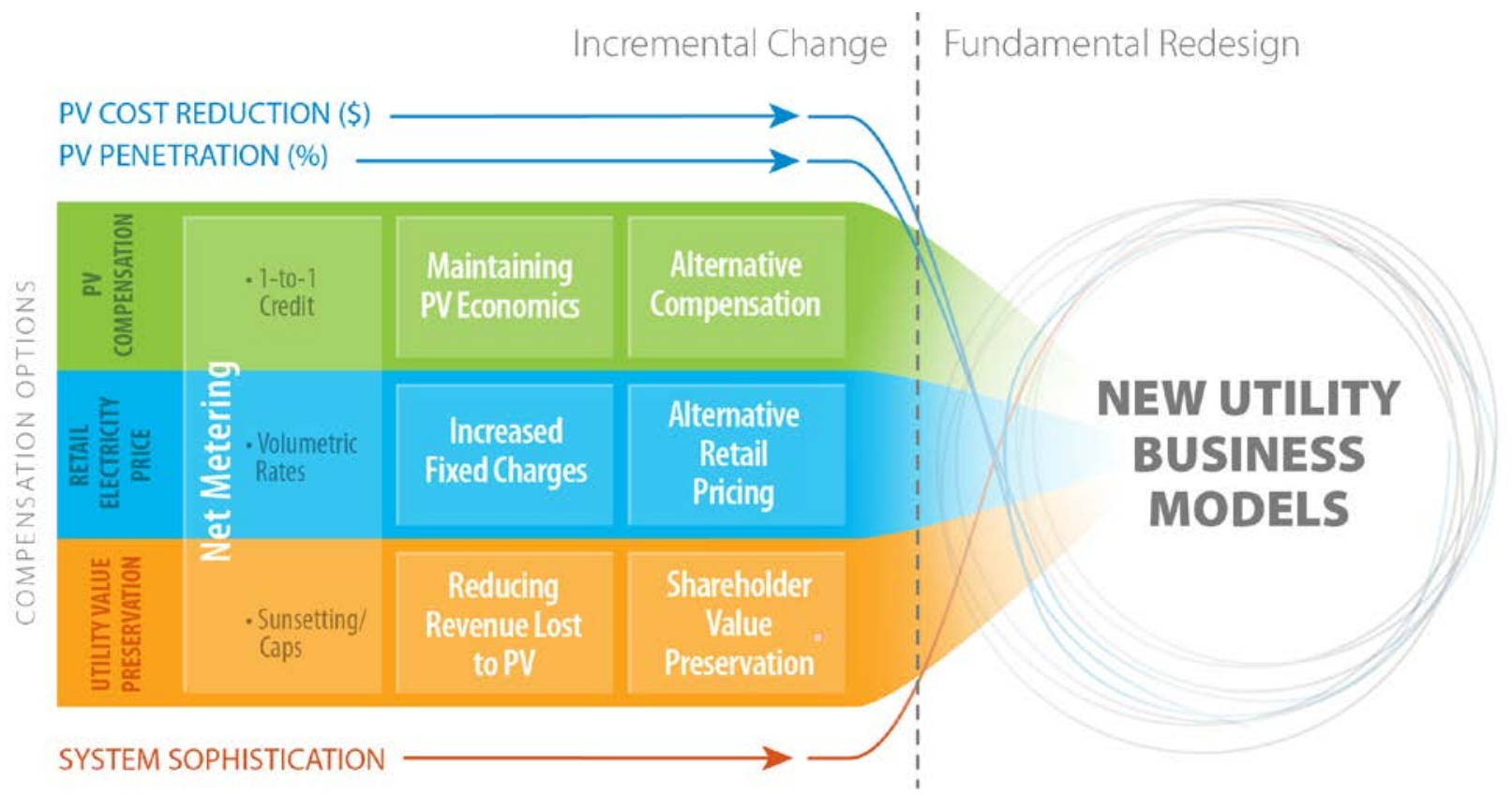

Figure ES-1. Compensation options grouped by category and level of complexity

DG compensation options can be thought of as building blocks that can be implemented relatively independently. Collectively, the options chosen to be implemented can form the policy that regulates PV customer compensation and utility revenue preservation.

Compensation options have been grouped in three categories: PV compensation, retail price, and utility value preservation, presented along the vertical in Figure ES-1. The horizontal arrows present an illustrative guide for the conditions that could trigger or justify compensation options. Options that are placed further right along the horizontal axis are generally more complex or expensive to implement and may not be cost-effective at low levels of DG penetration. 


\section{Distributed Generation Compensation Options}

Recent studies have found in general that current levels of distributed PV penetration do not significantly burden non-participant customers (CPUC 2013; E3 2014; VPSD 2013; Stanton et al. 2014). In scenarios in which non-participants or utilities are found to be adversely affected, declining levels of compensation pegged to relevant variables, such as DG penetration levels and PV costs, as opposed to time schedules, could reduce shifts in costs and avoid overcompensation while ensuring PV customers get a return on their investment.

New DG compensation mechanisms could reduce the potential for cost-shifting. Mechanisms such as value of solar tariffs and distributed locational marginal pricing could more fairly compensate solar production and grid services, but special attention should be given to dampening volatility to a level that offers certainty to customers-generators through incentives and long-term contracts. Compensating PV customers more accurately for the services their systems provide could send an economic signal to encourage PV owners to install and operate their systems in a way that benefits the broader electricity system.

Existing PV customers are especially vulnerable to adjustments to current policies or rates. Increased fixed costs and rate changes that decrease net compensation levels to existing PV owners negatively affect the economics of their systems, at a point in time when they have no recourse. Uncertainty could discourage potential investors and PV adopters. Grandfathering clauses reduce this risk by exempting existing owners from changes in rates and policies. In the case of alternative compensation mechanisms, such as value of solar tariffs, long-term contracts lock-in compensation rates for PV customers and increase certainty.

\section{Retail Electricity Pricing Options}

Increased monthly charges - in the form of fixed charges or minimum bills - in combination with current net metering policies may help utilities recover some of the capacity cost avoided by PV customers with near-net zero energy consumption. However, increased monthly charges may erode value for different stakeholders, including utilities' shareholders (Satchwell et al. 2014) and PV customers (Lazar 2014), and therefore should be carefully considered.

Retail pricing mechanisms that substitute volumetric charges and single fixed charges can be designed to help utilities fully recover the costs of serving their customers in high DG penetration scenarios. These include demand charges, real-time and time-of-use (TOU) rates, and attribute unbundling. More accurate retail pricing could ensure utilities' cost recovery without discouraging the adoption of new technologies (Glick et al. 2014). Additionally, these pricing mechanisms can send economic signals to PV customers to control their load and install their systems in a way that benefits the grid.

Assigning a value to the clean attributes of solar PV generation that are not currently priced, such as avoided carbon emissions, could offset the costs shifted to customers who use electricity from polluting sources. 


\section{Protecting Revenue Adequacy: Options for Utilities}

As penetration rates for distributed PV rise to substantial levels, coupling net metering-or alternative compensation mechanisms - with policies that mitigate utility revenue erosion could help preserve value system-wide and give stakeholders increased certainty. ${ }^{4}$

Net metering caps and sunsetting provisions could give utilities certainty that distributed solar will not reach levels that affect their financial stability without first being reviewed (Heeter et al. 2014).

Distributed PV has the potential to reduce the ability of utilities to recover its fixed costs. In jurisdictions where utilities revenues depend on unit sales of energy, distributed PV can have a detrimental effect on utilities' earnings at higher penetration levels. Options to reduce utility revenue lost to distributed PV include a shareholder incentive based on performance metrics (such as PV penetration goals) and regulatory approval for utilities to own distributed PV systems.

Revenue decoupling, lost revenue adjustments, and increasing the frequency of rate cases are options that may preserve utility shareholder value that may be lost if high PV penetration results in utility investment deferrals.

The options outlined above could help mitigate some of the conditions that lead to loss of value to utilities, PV customers, and non-participant customers. However, if the costs of distributed energy generation and storage technologies continue to decline to the point at which they trigger massive adoption, new utility regulation and business models may be needed to address a new environment with high penetration levels of lower-cost distributed energy resources.

The effects of net-metered PV on utility revenues and non-PV customers are smaller at lower penetration levels (CPUC 2013; Satchwell 2014). However, it may prove important to review and potentially recalibrate DG compensation as circumstances change. Deliberate changes that take into account the balance of interests among the different stakeholders involved may help preserve value across stakeholders and for society as a whole.

\footnotetext{
${ }^{4} \mathrm{DG}$ is only one of several factors that can reduce revenues for utilities. Others, such as energy efficiency and storage, are not covered in this study.
} 


\section{Table of Contents}

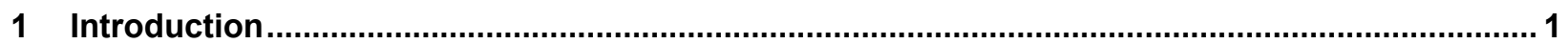

2 Current Distributed Generation Compensation Policies .......................................................... 4

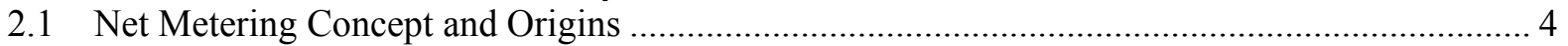

2.2 Impetus for Distributed Generation Compensation Reform ….............................................. 5

2.2.1 Impacts on Current Utility Business Models ............................................................... 7

2.2.2 PV Costs, Benefits, and Cost-Shifting ...................................................................... 9

3 Distributed Generation Compensation Changes Recently Proposed ......................................... 13

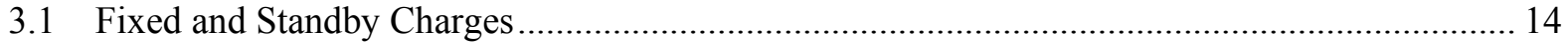

3.1.1 Fixed and Standby Charges Effects on Residential Solar PV Owners.......................... 15

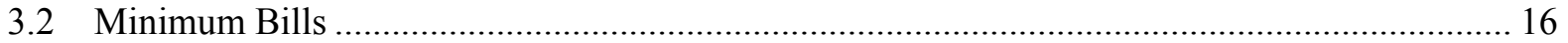

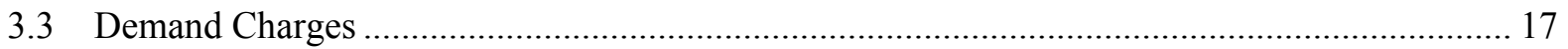

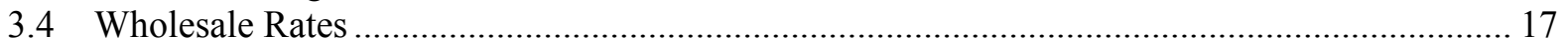

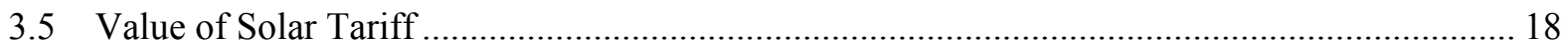

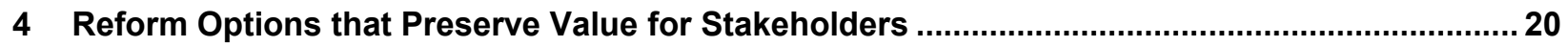

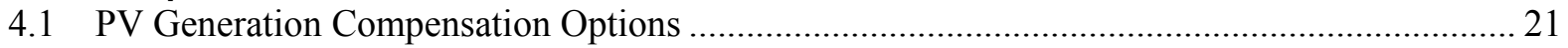

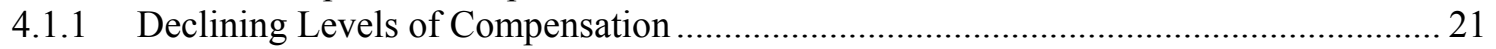

4.1.2 New Distributed Generation Compensation Options ................................................. 22

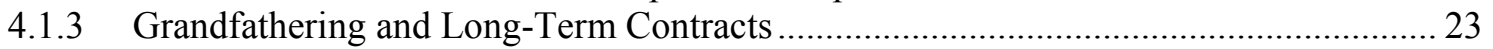

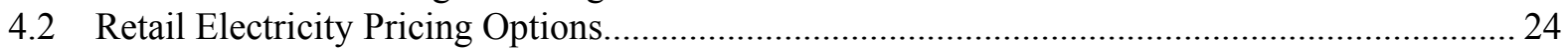

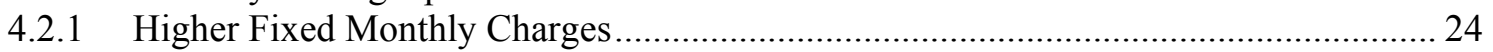

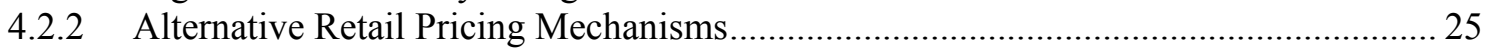

4.2.3 Paying for the Clean Attributes of PV Generation..................................................... 26

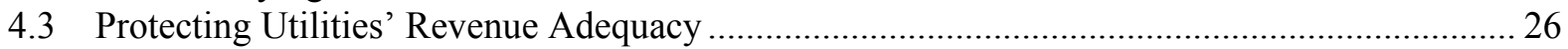

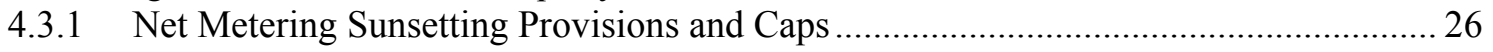

4.3.2 Reducing Utility Revenue Lost to Distributed PV ................................................ 27

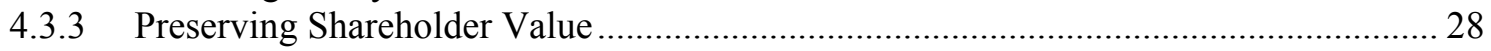

4.4 New Utility and Business Regulatory Models .............................................................. 28

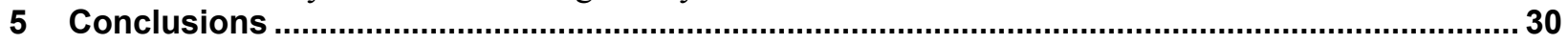

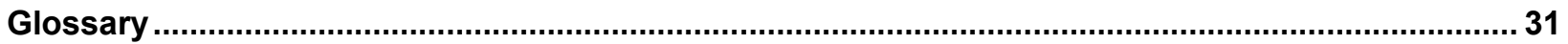

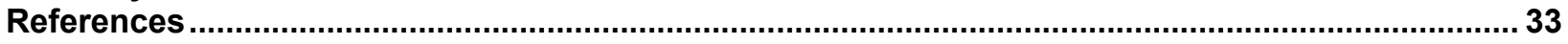

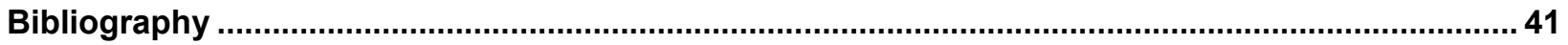

Appendix. PVWatts Simulation Parameters ................................................................................. 43

\section{List of Figures}

Figure 1. States where at least one NEM-related bill was introduced in 2014 and 2015........................ 1

Figure 2. States in which utilities have proposed a change in rate structures since 2013 that would reduce

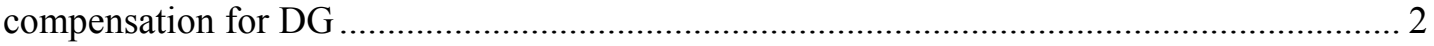

Figure 3. Compensation policies for net excess generation (NEG) by state as of August 2015................ 4

Figure 4. Cumulative number of net-metered customers in the United States and growth over previous

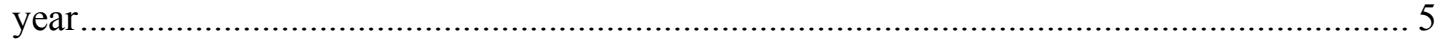

Figure 5. PV penetration effects on a vertically integrated utility .......................................................... 8

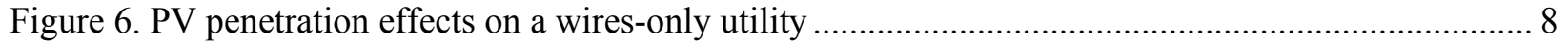

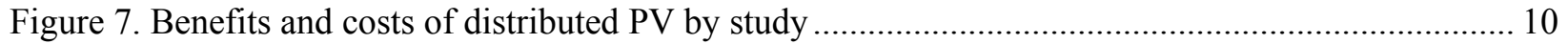

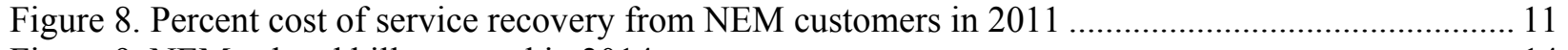

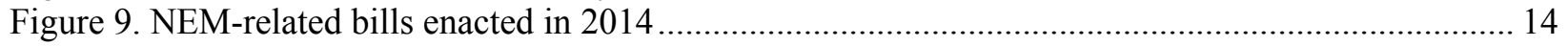

Figure 10. Relative weights for all the components in a 25-year levelized VOS calculation developed by the Minnesota Department of Commerce for illustrative purposes. ..................................... 18

Figure 11. Comparison between the net present value of VOS and NEM under different electricity price escalation rates and initial value of solar rate as a percentage of retail rate........................... 19 
Figure 12. Compensation options grouped by category and level of complexity

Figure 13. Historical auction SREC prices ....

Figure 14. Location of utility-owned PV systems by utility type.....

\section{List of Tables}

Table 1. Estimated DG as a Percentage of Total Retail Sales in the States with the Most DG ................... 6

Table 2. Utilities with Highest Proportion Of Energy Sold Back to Total Energy Sales ........................... 6

Table 3. Utilities with Highest Proportion of Net-Metered Customers to Total Customers......................... 7

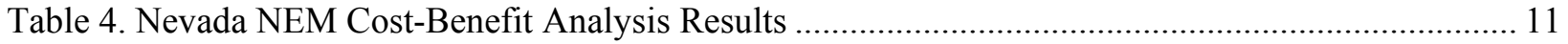

Table 5. Net-Metered PV System Benefits from the Ratepayer and State Perspectives in Vermont ......... 12

Table 6. Total Resource Cost Test Results Under Various Sensitivity Scenarios in Mississippi ............... 12

Table 7. Proposed Rate Changes and the Impacts on a Hypothetical 6-kW System ............................... 16

Table 8. Comparison Between Minimum Bills and Fixed Charges in Massachusetts (NStar utility

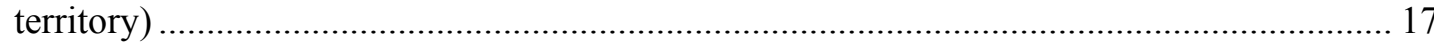




\section{Introduction}

Regulators, legislators, utilities, industry, and other stakeholders are working to evaluate and potentially amend net metering and other compensation mechanisms for distributed generation $(D G)^{5}$ in various jurisdictions of the United States. Several factors have prompted this reevaluation, including the accelerated adoption of distributed PV systems, declining solar PV system costs, and potential effects of DG on cost allocation and current utility business models.

Legislators in 29 states introduced bills to amend net metering provisions in 2014, and in 33 states in the 2015 legislative session as of August 20, 2015 (Haynes 2015) (Figure 1). In a 2014 survey, 99 utilities - around $75 \%$ of respondents - reported that they are considering rate restructuring and other alternatives to current net metering (NEM) policies to manage their impacts on revenue (Campbell and Taylor 2014; Makyhoun, Taylor, and Clark 2014). Since 2013, utilities in 27 states have filed proposals that would reduce distributed solar compensation levels (Figure 2).

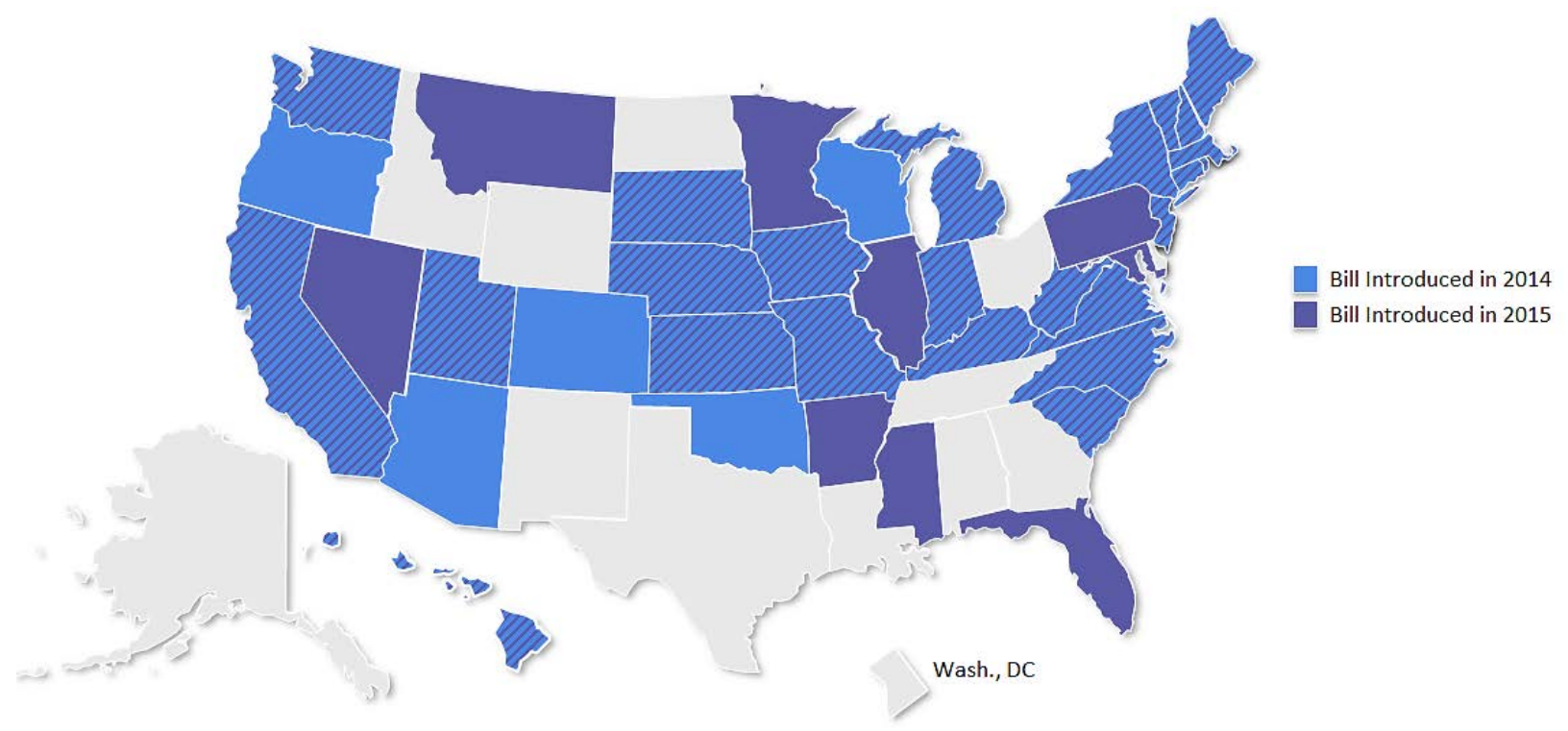

Figure 1. States where at least one NEM-related bill was introduced in 2014 and 2015 Source: Haynes 2015

NEM policies and compensation levels have remained relatively stable nationwide, despite the growing impetus and activity surrounding NEM reform (see Section 3). Grandfathering clauses have been implemented in some instances when NEM policies have changed, protecting the value of existing systems. However, regulatory uncertainty may still increase the cost of capital and reduce customer demand (SolarCity 2014), thus constraining the expansion of distributed PV deployment. Potential changes to net metering NEM policies represent a risk to the cash flows from existing or future distributed PV systems. Uncertainty about future distributed solar compensation policies matters because perceived regulatory instability may challenge renewable

\footnotetext{
${ }^{5}$ In this report, distributed generation refers to any customer-sited generation and distributed solar refers to customer-sited photovoltaics (PV) unless otherwise noted.
} 
energy deployment, increase capital costs, and reduce investment in general (Bhanot and Larsson 2014; Fabrizio 2012; IEA 2014).

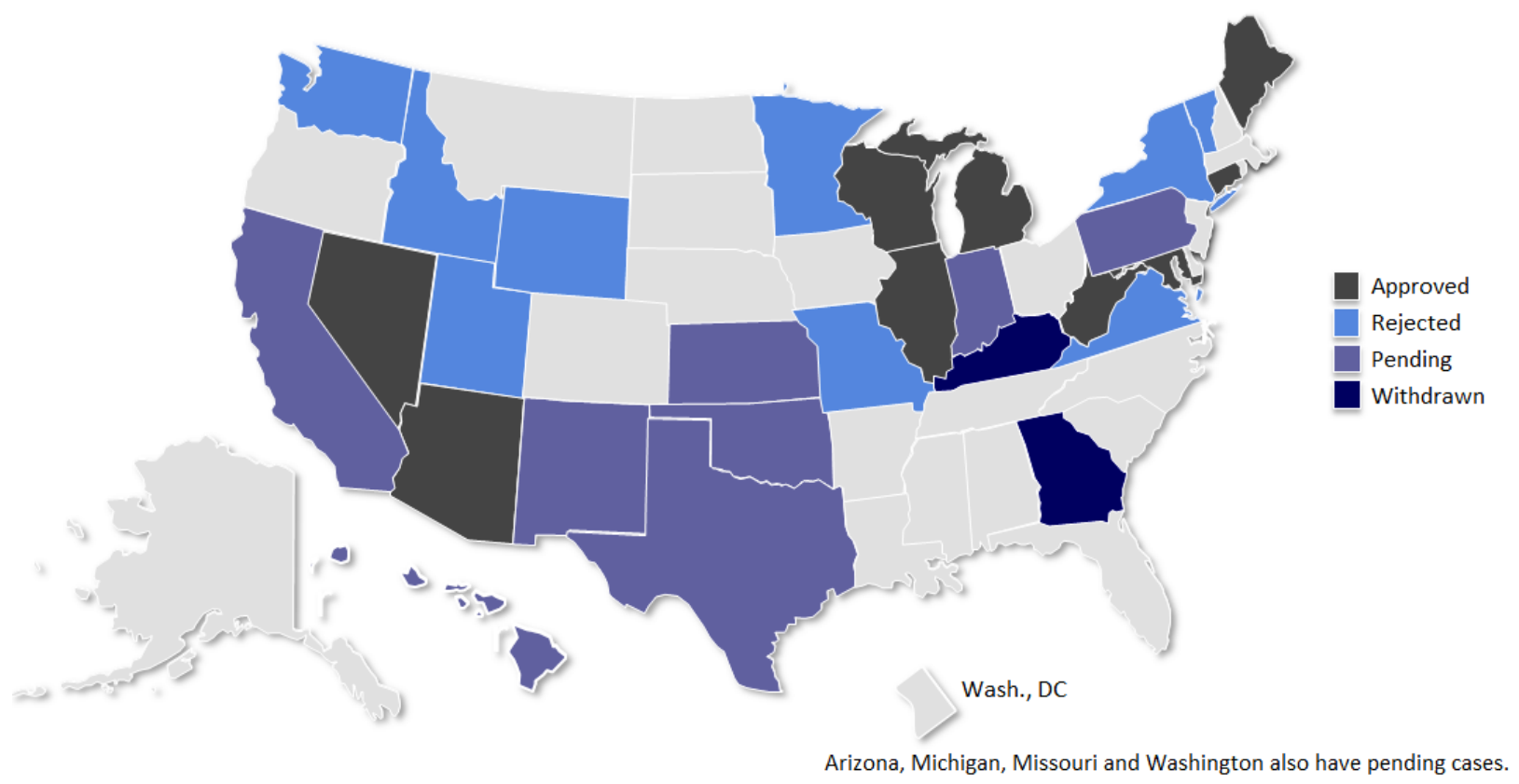

Figure 2. States in which utilities have proposed a change in rate structures since 2013 that would reduce compensation for DG

Sources: Hand 2015; Walton 2015; Roberts 2015; Inskeep et al. 2015; EQ Research 2015

As the relevant stakeholders work to amend net metering policies to balance public and private interests, an understanding of recent trends and potential effects can be useful to assess risks and minimize the adverse effects of uncertainty. This report reviews current distributed generation compensation policies in the United States and summarizes the issues prompting states to revise those policies. It also examines the recent rate redesign proposals that affect DG compensation and quantifies the impact some of these proposed changes could have on the economics of distributed PV systems. Finally, this report presents DG compensation options that can be implemented - independently or in combination - to provide stakeholders with certainty and preserve stakeholder value. This report does not intend to be an exhaustive or in-depth review of all the DG compensation options available. 


\section{Text Box 1: Effects of Uncertainty on Solar Securitization}

Securitization is a financing technique that aggregates pools of assets, such as solar leases, and transforms their future cash flows into a financial instrument that can be traded for capital. The resulting tradable instrument is called an asset-backed security. Securitization transfers the rights to the cash flows, and some of the risks, to the investors (PwC 2013; Lowder and Mendelsohn 2013).

The securitization of solar assets can support the expansion of the PV industry by enabling it to enlarge and diversify its sources of funding. Additionally, capital raised through securitization generally has lower costs than the industry's most common sources of funding, namely debt, tax equity, and sponsor equity. Increasing the use of public capital to finance renewable energy projects through securitization and other financial instruments could lower the cost of installed PV systems and accelerate solar deployment (Mendelsohn and Feldman 2013).

NEM policy uncertainty can affect securitization efforts. In its rating for SolarCity's 2013 securitization deal, the rating agency Standard \& Poor's identified "legislative pressure" as a source of uncertainty to the economics and cost savings of distributed PV assets (S\&P 2013). Changes in NEM laws and regulations can impact the value of solar asset-backed securities by changing the cash flows from solar assets. Investors may demand a premium to compensate for regulatory uncertainty (Bhanot and Larsson 2014), thus increasing the cost of capital obtained through securitization. 


\section{Current Distributed Generation Compensation Policies}

\subsection{Net Metering Concept and Origins}

Net metering credits owners of DG sources for energy produced that is not instantaneously consumed on site. Typically, each kilowatt hour $(\mathrm{kWh})$ exported to the grid is credited as a $\mathrm{kWh}$ that can be used at a later time in the same billing cycle. NEM policies may also have a carryover provision that allows the use of credits in a subsequent billing cycle. At the end of the net metering cycle, typically one year, net excess generation may be credited at wholesale rates, rolled over, or forfeited (Figure 3). NEM mechanisms offer the benefits of administrative and structural simplicity (Rábago 2013).

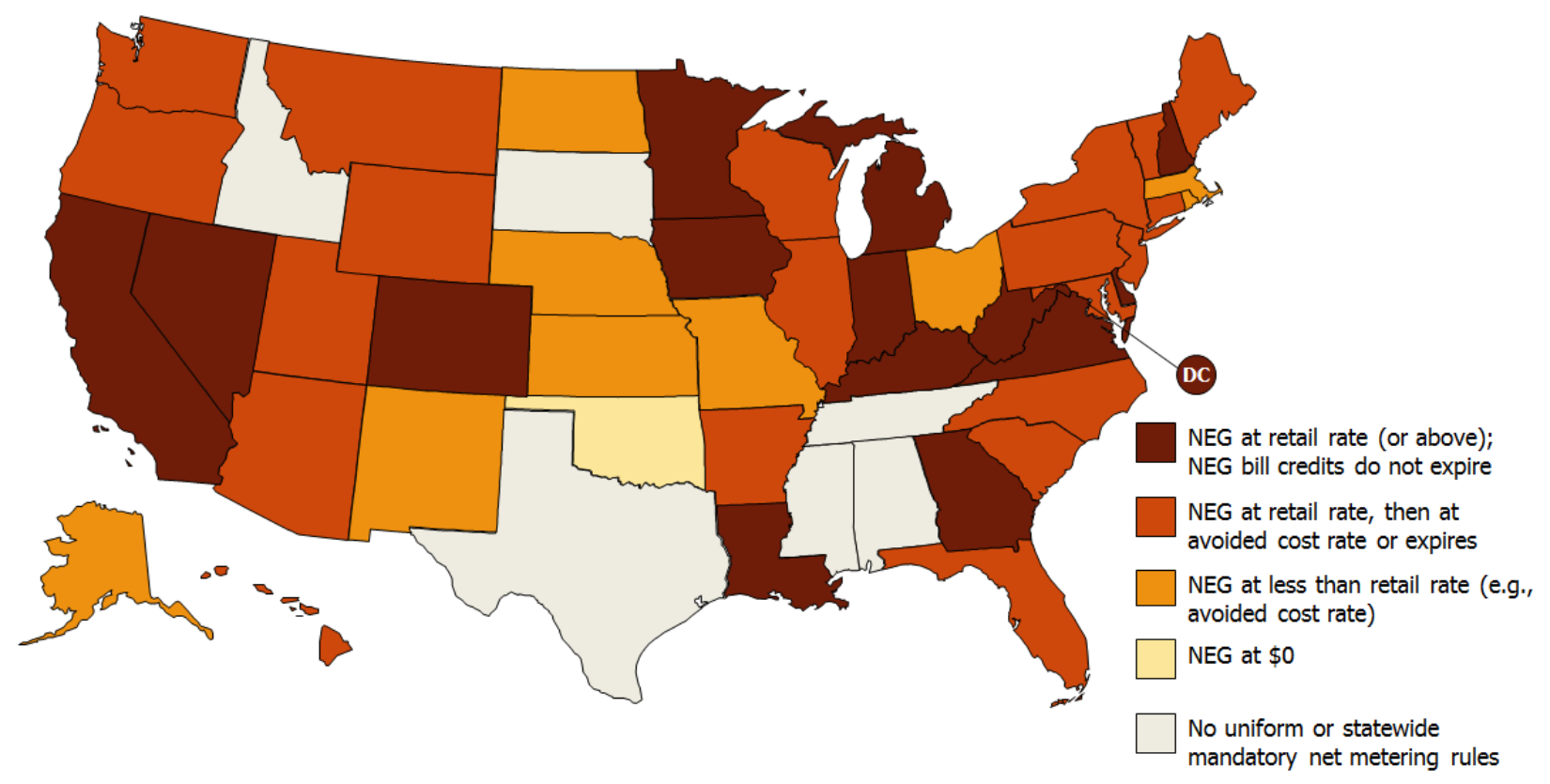

Figure 3. Compensation policies for net excess generation (NEG) by state as of August 2015

Source: DSIRE, 2014, updated with information from DSIRE (http://programs.dsireusa.org) and Freeing the Grid (http://freeingthegrid.org).

The implementation of net metering programs dates back to the 1980s (Wan and Green 1998). By 2003, utilities in 38 states and the District of Columbia had net-metered customers (EIA 2012). The Energy Policy Act of 2005 (EPAct 2005) amended the Public Utility Regulatory Policies Act (PURPA) to state that each "electric utility shall make available upon request net metering service to any electric consumer that the electric utility serves" (16 U.S.C. 2621(d)(11), and directs all state utility commissions (and non-regulated utilities) to consider the adoption of a net metering standard (H.R. 6-109 ${ }^{\text {th }}$ Congress: Energy Policy Act of 2005).

In most states, NEM eligibility is not limited to solar PV systems; however, by the end of 2013, $95 \%$ of the customer-generated energy compensated by utilities through NEM programs came from PV systems (EIA 2015a). 
NEM policies are set and administered at the state level by lawmakers and regulators. Forty-four states and Washington D.C. have adopted net metering policies (Durkay 2014). Twenty-five states have caps in their NEM programs, which restrict the total eligible capacity. Three states have policies that trigger program revisions or notification measures when a certain level of netmetered capacity is reached, without necessarily suspending NEM programs. Hawaii's net metering limits are based on individual circuit penetration levels: when the cap of $15 \%$ of circuit peak demand is reached, utilities may perform a study to determine if the limit can be increased. New Jersey and other states have reached or nearly reached caps but have raised them in response. Massachusetts, Delaware, California, Nevada, and New York are projected to reach their caps between 2015 and 2017. Of the rest of the states, only Vermont is projected to reach its cap before 2020 (Heeter et al., 2014).

Utilities in states with utility-level limits_-including California, Massachusetts, New York, and New Hampshire - have reached NEM limits, or are expected to reach them in 2015. The Public Service Commission in New York has directed utilities to continue to accept NEM applications until a successor tariff is approved (CUNY 2015). Other utilities have suspended their NEM programs or added new applicants to waiting lists (EQ Research 2014; MassACA 2015).

\subsection{Impetus for Distributed Generation Compensation Reform}

Several factors have prompted stakeholders to call attention to NEM policies, including the accelerated adoption of net-metered PV systems (Steward 2014) (Figure 4), improvements in solar technologies that may continue to reduce costs, innovative financing mechanisms that facilitate solar mainstream adoption, potential financial risks to current utility business models posed by higher levels of distributed PV penetration (Kind 2013), and distribution network reliability concerns in high-deployment scenarios.

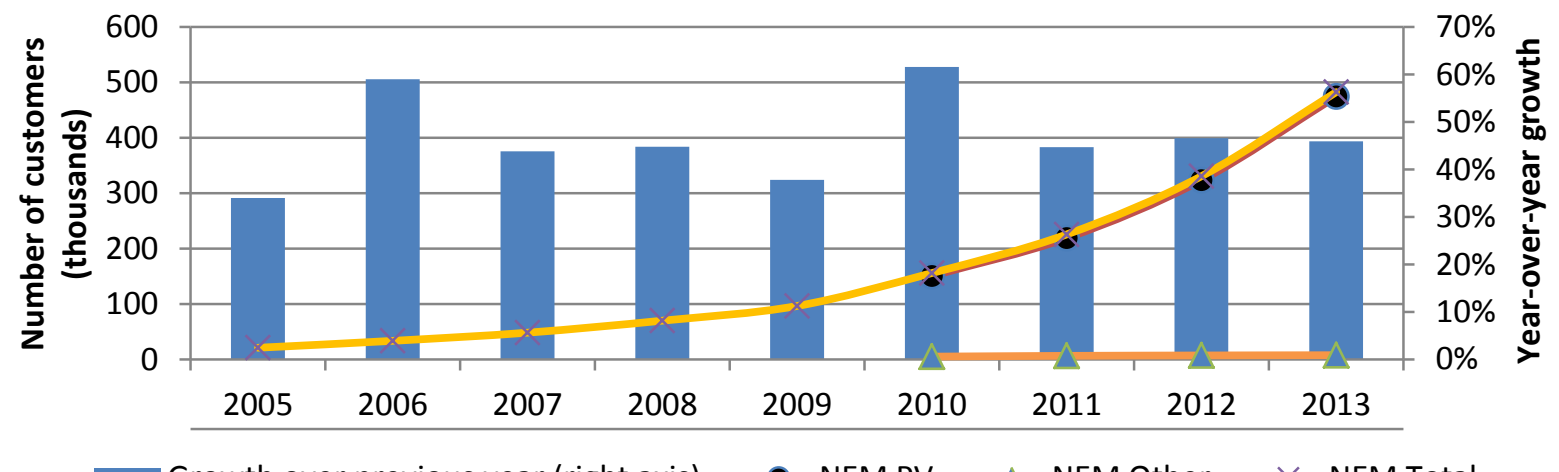

Figure 4. Cumulative number of net-metered customers in the United States and growth over previous year

Source: EIA 2015a. System technology breakdown data available only from 2010 and on.

According to 2013 data, the average proportion of energy compensated under NEM programs to total utility retail sales is less than two hundredths of a percent at the national level (EIA 2015b). Hawaii, New Jersey, and California have the highest penetration rates of distributed PV at the state level (Table 1). 
Table 1. Estimated DG as a Percentage of Total Retail Sales in the States with the Most DG

\begin{tabular}{|l|r|r|r|r|}
\hline State & \multicolumn{1}{|l|}{$\begin{array}{l}\text { Distributed } \\
\text { Capacity (MW) }\end{array}$} & $\begin{array}{l}\text { Estimated } \\
\text { production }(\mathbf{M W h})^{\text {a }}\end{array}$ & $\begin{array}{l}\text { Total Retail Sales } \\
(\mathbf{M W h})\end{array}$ & $\begin{array}{l}\text { \% of Total } \\
\text { Retail Sales }\end{array}$ \\
\hline Hawaii & 308 & 404,712 & $9,503,164$ & $4.3 \%$ \\
\hline New Jersey & 1,048 & $1,377,072$ & $113,233,316$ & $1.2 \%$ \\
\hline California & 2,428 & $3,190,392$ & $287,077,093$ & $1.1 \%$ \\
\hline Arizona & 461 & 605,754 & $75,662,037$ & $0.8 \%$ \\
\hline Massachusetts & 388 & 509,832 & $80,751,947$ & $0.6 \%$ \\
\hline Colorado & 225 & 295,650 & $53,441,649$ & $0.6 \%$ \\
\hline
\end{tabular}

Sources: SEIA/GTM 2014; EIA 2015b, with data from 2013

${ }^{\text {a }}$ Estimated production is based on a nation-wide $15 \%$ capacity factor.

By the end of 2013, some individual utilities had reached NEM levels of up to $2 \%$ measured as the ratio of energy sold back to utilities as part of NEM programs to total retail sales (Table 2). Thirteen utilities in the United States have more than 2\% of customers participating in net metering programs. Hawaiian Electric Company, an investor-owned utility in Hawaii, tops the list with 9.4\% (Table 3) (EIA 2015b). ${ }^{6}$

Table 2. Utilities with Highest Proportion Of Energy Sold Back to Total Energy Sales

\begin{tabular}{|l|l|r|r|r|}
\hline Utility (State) & Type & \multicolumn{1}{l|}{$\begin{array}{l}\text { Total Retail } \\
\text { Sales (MWh) }\end{array}$} & $\begin{array}{l}\text { Energy } \\
\text { Sold Back } \\
\text { (MWh) }\end{array}$ & \multicolumn{2}{l}{$\begin{array}{l}\text { \% of Total } \\
\text { Sales }\end{array}$} \\
\hline Hawaii Electric Light Co., Inc. (HI) & Investor-Owned & $1,076,104$ & 21,060 & $2.0 \%$ \\
\hline Kauai Island Utility Cooperative (HI) & Cooperative & 431,478 & 7,177 & $1.7 \%$ \\
\hline NSTAR Electric Company (MA) & Investor-Owned & $8,521,681$ & 97,252 & $1.1 \%$ \\
\hline City of Alameda (CA) & Municipal & 363,444 & 3,395 & $0.9 \%$ \\
\hline Turlock Irrigation District (CA) & Public District & $1,975,891$ & 18,074 & $0.9 \%$ \\
\hline Tucson Electric Power Co. (AZ) & Investor-Owned & $9,278,919$ & 48,734 & $0.5 \%$ \\
\hline
\end{tabular}

Source: EIA 2015b, with data from 2013

\footnotetext{
${ }^{6}$ Data as reported in Form EIA-861. Not all utilities report energy credited to PV customers as part of net metering programs.
} 
Table 3. Utilities with Highest Proportion of Net-Metered Customers to Total Customers

\begin{tabular}{|l|l|l|r|r|}
\hline Utility (State) & Type & $\begin{array}{l}\text { Total } \\
\text { Customers }\end{array}$ & $\begin{array}{l}\text { Net- } \\
\text { Metered } \\
\text { Customers }\end{array}$ & $\begin{array}{l}\text { \% of Total } \\
\text { Customers }\end{array}$ \\
\hline Hawaiian Electric Co., Inc. (HI) & Investor-Owned & 298,920 & 28,215 & $9.4 \%$ \\
\hline Maui Electric Co. Ltd. (HI) & Investor-Owned & 69,284 & 5,206 & $7.5 \%$ \\
\hline Hawaii Electric Light Co., Inc. (HI) & Investor-Owned & 82,268 & 5,336 & $6.5 \%$ \\
\hline Kauai Island Utility Cooperative (HI) & Cooperative & 33,060 & 1,793 & $5.4 \%$ \\
\hline Town of Concord (MA) & Municipal & 8,100 & 212 & $2.6 \%$ \\
\hline Sulphur Springs Valley E C Inc. (AZ) & Cooperative & 50,807 & 1,285 & $2.5 \%$ \\
\hline
\end{tabular}

Source: EIA 2015b, with data from 2013

\subsubsection{Impacts on Current Utility Business Models}

Current utility business models are being challenged by numerous factors, such as declining demand growth rates and falling costs of distributed energy resources (Kind 2013). Distributed PV may pose challenges to current utility business models at higher penetration rates. First, higher penetration rates could defer investments in new generation plants and therefore reduce the opportunities for utility shareholders to earn a return. Second, higher DG penetration rates may reduce energy sales, causing an increase in rates as utilities strive to recover fixed costs from fewer electricity sale units (i.e., $\mathrm{kWh}$ ).

In 2014, Lawrence Berkeley National Laboratory (LBNL) found that increased levels of netmetered electricity generation could have negative effects on utilities' earnings and shareholder returns. Two types of utilities were modeled in LBNL's study: vertically integrated and wiresonly. The study estimated changes on utility shareholder return on equity (ROE), earnings, and average rates at four different levels of net-metered PV penetration, compared to a baseline with no distributed PV. Penetration rates in this study were measured as the ratio of total generation from distributed PV systems to total retail sales in a utility's territory (which is different to the proportions shown in Tables 2 and 3) (Satchwell et al. 2014).

The results for the vertically integrated utility showed that, at a $10 \%$ penetration level, ROE could decline $2.9 \%$, earnings $8.1 \%$, and rates would increase $2.5 \%$ (Figure 5 ). For the same penetration level, the wires-only utility would see ROE and earnings declines of $18.1 \%$ and $15.4 \%$, respectively, and a retail rate increase of $2.7 \%$ (Figure 6). By the end of 2013, the investor-owned utilities in the United States with distributed PV penetration rates of $2 \%$ and above were Hawaiian Electric Co., Maui Electric Co., Hawaii Electric Light Co., Pacific Gas \& Electric, San Diego Gas \& Electric, and Arizona Public Service (Satchwell et al. 2014). 


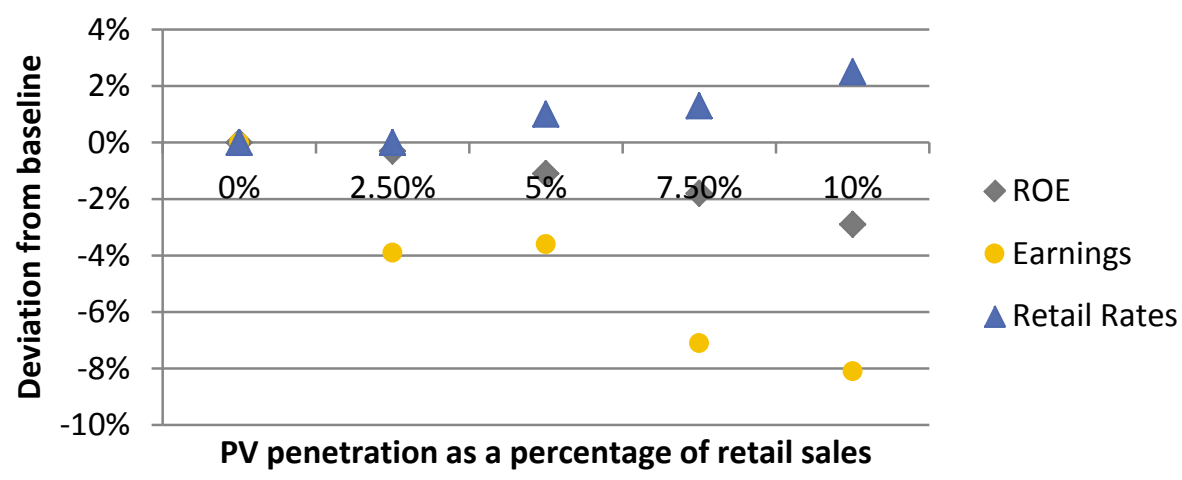

Figure 5. PV penetration effects on a vertically integrated utility

Source: Satchwell et al. 2014

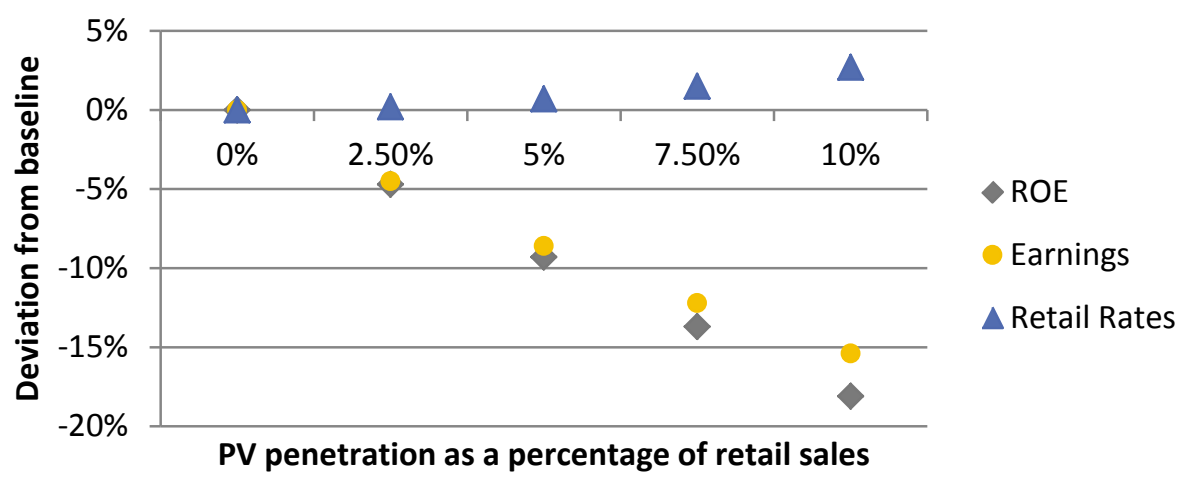

Figure 6. PV penetration effects on a wires-only utility

Source: Satchwell et al. 2014

Negative effects on earnings and ROE can create an incentive for utilities to discourage customer investments in DG or seek to modify NEM policies (Gordon and Olson 2004). Section 3 discusses changes proposed by utilities, among other stakeholders, in response to these challenges. 


\section{Text Box 2: Cost-Shifting}

Utilities most commonly depend on the volumetric component (i.e., based on the volume of energy (kWh) sold) of residential rates to recover energy and capacity costs. The capacity costs associated with serving this customer class, mostly related to transmission and distribution (T\&D) infrastructure construction and maintenance, may amount to slightly under one half of total costs (EPRI 2014a) and may not be recovered in billing cycles when PV customers consume little or no energy. As the number of PV customers increases in their territories, utilities' reliance on volumetric charges may threaten their ability to recover costs (Gordon and Olson 2004; Brown 2014). Alternatively, unrecovered costs could be shifted toward customers who do not own DG systems (Black \& Veatch 2014). However, DG may not be the only source of cost-shifting embedded in electricity rates. Larger customers typically pay more for electricity than other customers within the same rate class, for example (Overcast 2015; Pentland 2014). A study published by the California Public Utilities Commission found that, although NEM is causing a shift in costs in the state, PV customers are still paying in average $103 \%$ of their full cost of service. DG in this case helped correct a previously existing shift in costs (CPUC 2013).

\subsubsection{PV Costs, Benefits, and Cost-Shifting}

A number of studies evaluating the costs, benefits, or both, that distributed PV and NEM impose on the system - some including the magnitude of cost-shifting-have been completed in the last few years. The results vary according to methodologies used and assumptions made on variables of unknown future value, such as the cost of natural gas and other fuels used for electricity generation, in addition to differences in the actual costs and benefits of distributed PV and other forms of DG in different locations and utility systems. Direct result comparison is difficult also because the analyses vary in their perspectives. The net value of distributed PV generation can be assessed from a rate-impact perspective, a total resource cost perspective, and many other perspectives that change the depth and scope of the analysis, as well as the number and type of sources of PV value (SEPA 2013).

A report collecting the results of 16 distributed PV cost and benefit studies - previously published by utilities, national laboratories, and other organizations - shows benefits ranging from approximately $\$ 0.035 / \mathrm{kWh}$ to $\$ 0.34 / \mathrm{kWh}$, and costs of up to $\$ 0.35 / \mathrm{kWh} .^{7}$ The report notes that differences in assumptions and methodologies do not permit a direct comparison among results. Figure 7 presents distributed PV benefits as positive quantities, and costs as negative (RMI 2013).

\footnotetext{
${ }^{7}$ Some studies considered only benefits.
} 


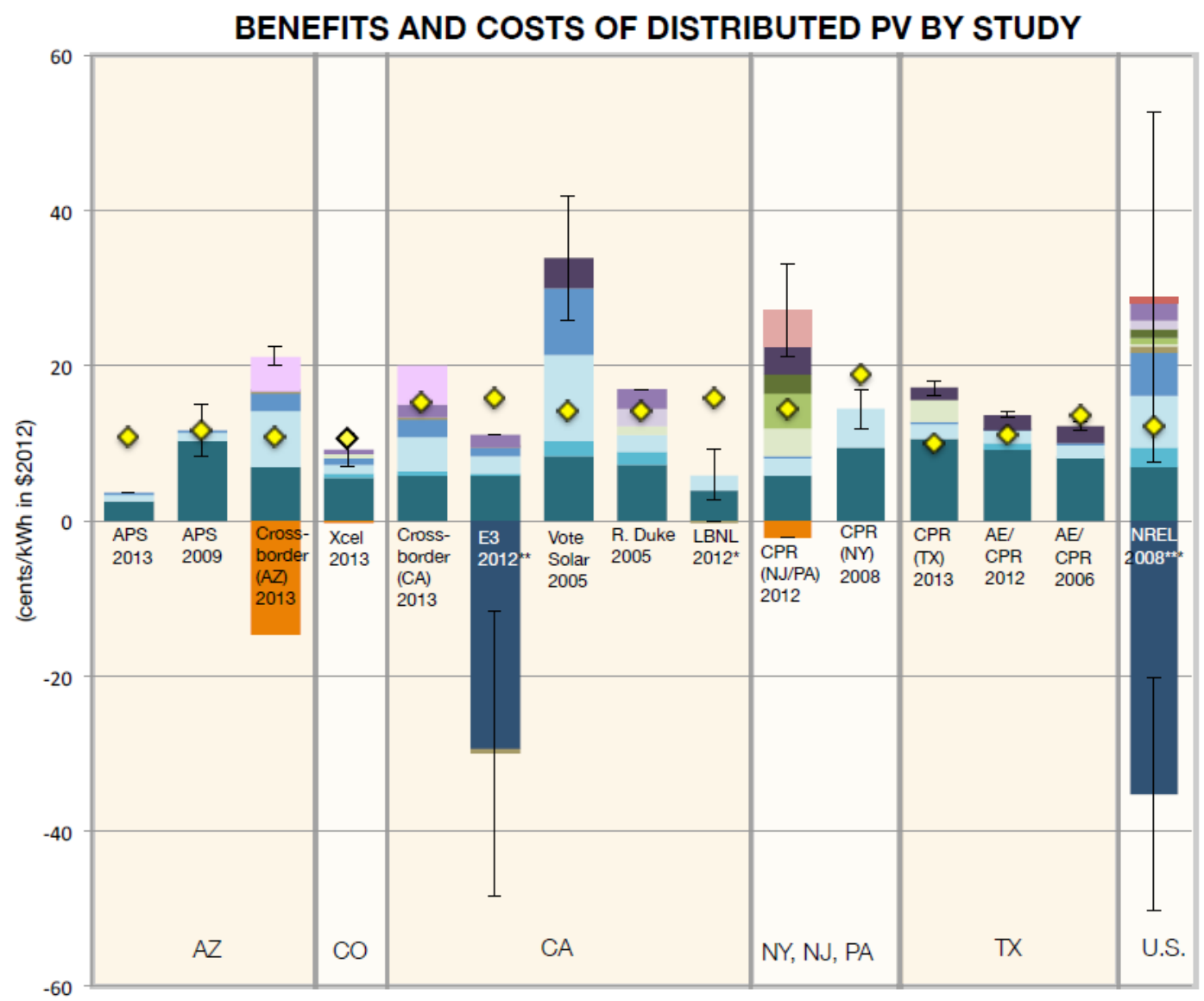

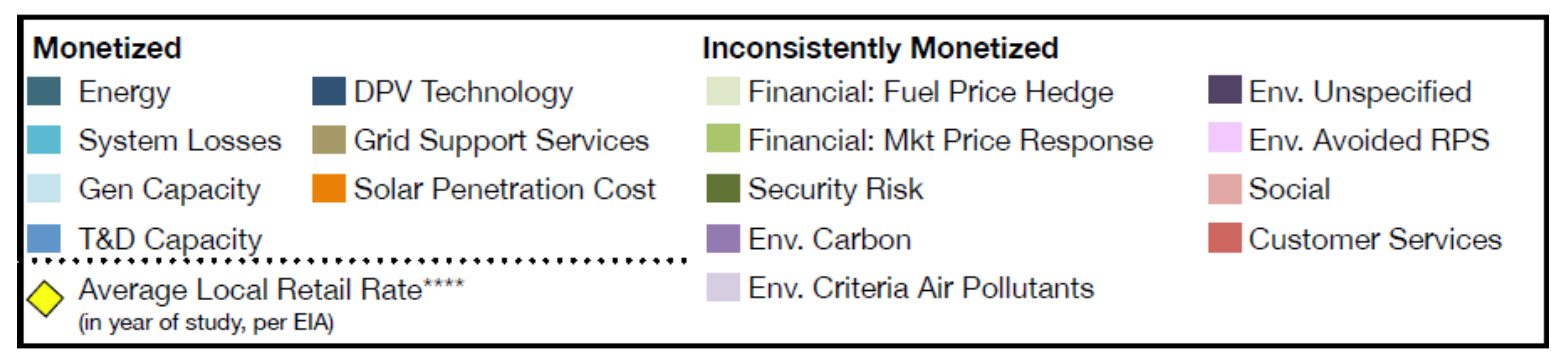

Figure 7. Benefits and costs of distributed PV by study

Source: RMI 2013

\section{Text Box 3: Monetizing Externalities}

Certain financial, security, environmental, and social benefits included in some distributed PV cost-benefit analyses are not monetized in current ratemaking processes. Consequently, these benefits may not help alleviate cost-shifting and cost recovery issues, even if the estimated value of distributed PV benefits is comparable or higher than costs (RMI 2013). Furthermore, valuing some of these benefits may be challenging because the benefits cannot be determined precisely (EPRI 2014b).

Legislatures and regulatory commissions in several states have also commissioned studies to assess costs and benefits of DG and whether cost-shifting is occurring and, if so, at what level. The results of some of these studies could impact NEM compensation or associated rates. Recent results range from modest net costs to modest net benefits to all ratepayers: 
- A study commissioned by California's legislature estimated that the net cost impact from NEM generation to all ratepayers could be between $\$ 370$ million and $\$ 1.1$ billion (i.e., between $1.1 \%$ and $3.1 \%$ of total investor-owned utility revenue requirement) when NEM capacity reaches $5 \%$ of the sum of non-coincident customer peak demand. The study also found that net-metered customers pay $103 \%$ of their full cost of service (Figure 8) (CPUC 2013).

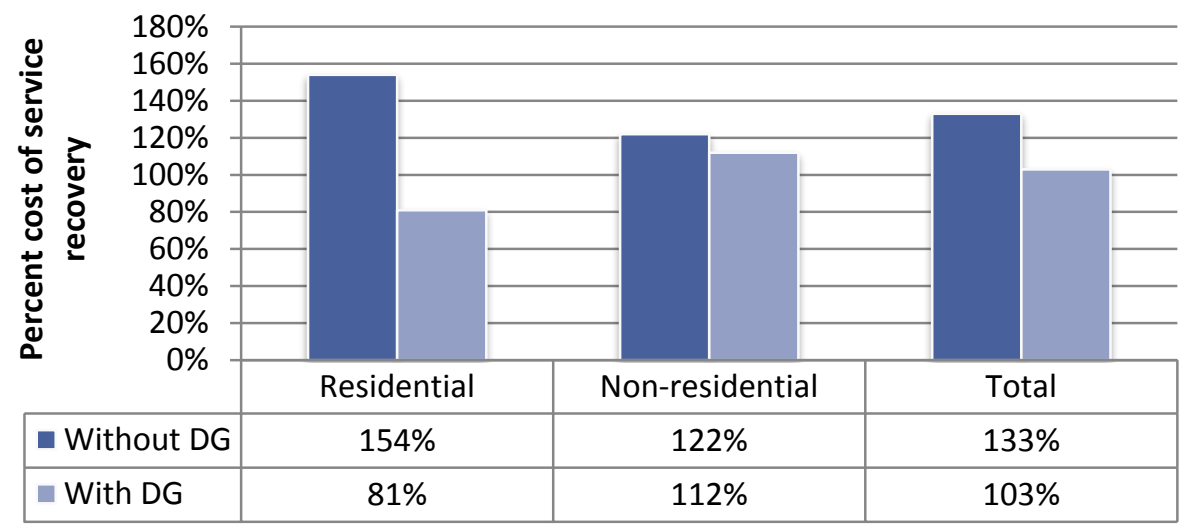

Figure 8. Percent cost of service recovery from NEM customers in 2011

Source: CPUC 2013

- An analysis completed at the request of the legislature in Nevada found that the costs and benefits of NEM are nearly even under current and proposed scenarios and that the impacts on non-participants (which were estimated to be positive or negative, depending on assumptions) would not be substantial (E3 2014).

Table 4. Nevada NEM Cost-Benefit Analysis Results

\begin{tabular}{|c|c|c|c|}
\hline \multirow[b]{3}{*}{ Test } & \multirow[b]{3}{*}{ Result Description } & \multicolumn{2}{|c|}{ All Installations Through 2016} \\
\hline & & \multicolumn{2}{|c|}{ Lifecycle NPV \$MM 2014} \\
\hline & & Base Case & $\begin{array}{l}\text { Including Distribution } \\
\text { Avoided Costs }\end{array}$ \\
\hline $\mathrm{RIM}^{\mathrm{a}}$ & Benefit (cost) to non-participating customers & $\$ 36$ & $\$ 166$ \\
\hline $\mathrm{PACT}^{\mathrm{b}}$ & Reduction (increase) in aggregate customer bills & $\$ 716$ & $\$ 847$ \\
\hline $\mathrm{TRC}^{\mathrm{c}}$ & Benefit (cost) to the state of Nevada & $(\$ 100)$ & $\$ 31$ \\
\hline $\mathrm{SCT}^{\mathrm{d}}$ & Benefit (cost) to the state of Nevada, incl. externalities & $(\$ 75)$ & $\$ 82$ \\
\hline
\end{tabular}

${ }^{a}$ Rate Payer Impact; ${ }^{b}$ Program Administrator Cost Test; ${ }^{c}$ Total Cost Resource; ${ }^{d}$ Societal Cost Test Source: E3 2014. NPV = net present value.

- A study conducted by the Vermont Public Service Department looking specifically at the question of cost-shifting found that net-metered PV systems do not impose a significant net cost to the state or ratepayers. PV systems provided net benefits in every scenario when the cost of greenhouse gas (GHG) emissions was factored in (VPSD 2013). 
Table 5. Net-Metered PV System Benefits from the Ratepayer and State Perspectives in Vermont

\begin{tabular}{|l|l|c|l|l|}
\multirow{2}{*}{} & \multicolumn{4}{|c|}{ Perspective } \\
\cline { 2 - 5 } & \multicolumn{2}{|c|}{ Ratepayer $(\$ / k W h)$} & \multicolumn{2}{c|}{ State $(\$ / k W h)$} \\
\hline Net benefit, no GHG value included & Lower & Upper & Lower & Upper \\
\hline Net benefit, GHG value included & $(\$ 0.021)$ & $(\$ 0.006)$ & $(\$ 0.015)$ & $\$ 0.000$ \\
\hline
\end{tabular}

Source: VPSD 2013

- The Mississippi Public Service Commission requested a cost-benefit analysis that found that NEM would provide a net benefit to the state from a total resource perspective under most scenarios considered. Sensitivities analyzed included oil and natural gas price volatility, PV capacity value in wholesale markets, avoided transmission and distribution costs, and carbon dioxide $\left(\mathrm{CO}_{2}\right)$ price (Stanton et al. 2014). Each scenario used the low, middle, or high estimate for each of the variables considered in the study (Table 6).

Table 6. Total Resource Cost Test Results Under Various Sensitivity Scenarios in Mississippi

\begin{tabular}{|l|l|l|l|}
\multirow{2}{*}{\multicolumn{1}{c|}{ Scenarios }} & \multicolumn{3}{c|}{ Total Resource Cost Test ${ }^{8}$} \\
\cline { 2 - 4 } \multicolumn{1}{c|}{} & Low & \multicolumn{1}{c|}{ Mid } & \multicolumn{1}{c|}{ High } \\
\hline Fuel Price & 1.17 & 1.19 & 1.21 \\
\hline Capacity Value & 1.11 & 1.19 & 1.26 \\
\hline Avoided T\&D & 1.01 & 1.19 & 1.32 \\
\hline $\mathrm{CO}_{2}$ Price & 1.16 & 1.19 & 1.24 \\
\hline Combined Scenario & 0.89 & 1.19 & 1.47 \\
\hline
\end{tabular}

Source: Stanton et al. 2014

- In Oregon, a report completed at the request of the legislature stated that some of the costs embedded in electricity rates to maintain the grid may be shifted to ratepayers who do not own DG systems. The authors of the report recommend the public utility commission open a formal proceeding to assess whether cost-shifting occurs as a result of NEM (Public Utility Commission of Oregon 2014).

- Minnesota recently completed a study to establish a value of solar tariff. The methodology has been finalized and approved, although it has not been applied yet (Tomich 2014). In its testimony during the proceedings, Xcel Energy estimated a value of solar rate of $\$ 0.145 / \mathrm{kWh}$, compared to average statewide electricity costs of $\$ 0.1285 / \mathrm{kWh}$ for residential customers (Xcel Energy 2014; EIA 2014).

\footnotetext{
${ }^{8}$ The Total Resource Cost (TRC) test is a measure of cost-effectiveness and can be expressed as a ratio (benefits/costs) with no unit of measurement. TRC values of 1 or higher indicate net benefits.
} 


\section{Distributed Generation Compensation Changes Recently Proposed}

Some utilities, regulators, legislators, and other stakeholders have proposed and initiated actions that change the way net-metered customers are compensated for the energy they produce.

In 2013 and 2014, 20 utilities serving more than 15 million customers in 16 states filed proposals that would reduce distributed solar compensation levels. Currently, public utility commissions in eight states are reviewing proposals filed by utilities to increase fixed charges (Figure 2). Utilities seeking to modify rate structures, even those with low percentages of net-metered customers, have expressed the need to address NEM-related cost recovery or cost-shifting issues through rate redesign (Steward 2014; WPS 2014).

Proposed changes can be either applied to net-metered customers or to a whole customer class. Proposed changes typically target residential and small commercial customers because larger customers pay demand charges that offset fixed utility costs.

In 2014, 12 states enacted laws related to net metering. Ten of the enacted bills established, clarified, or expanded the state's NEM policy. Enacted laws in two states may reduce the benefits for net-metered systems. Kansas enacted legislation that reduces the availability of NEM and could result in additional charges for NEM customers in the future. Oklahoma enacted legislation that could also result in additional charges for NEM customers, potentially making ownership of distributed renewables less attractive. Utah's Senate Bill 208 is marked as neutral in Figure 9 because its consequences depend on the results of a study required by the legislature. 


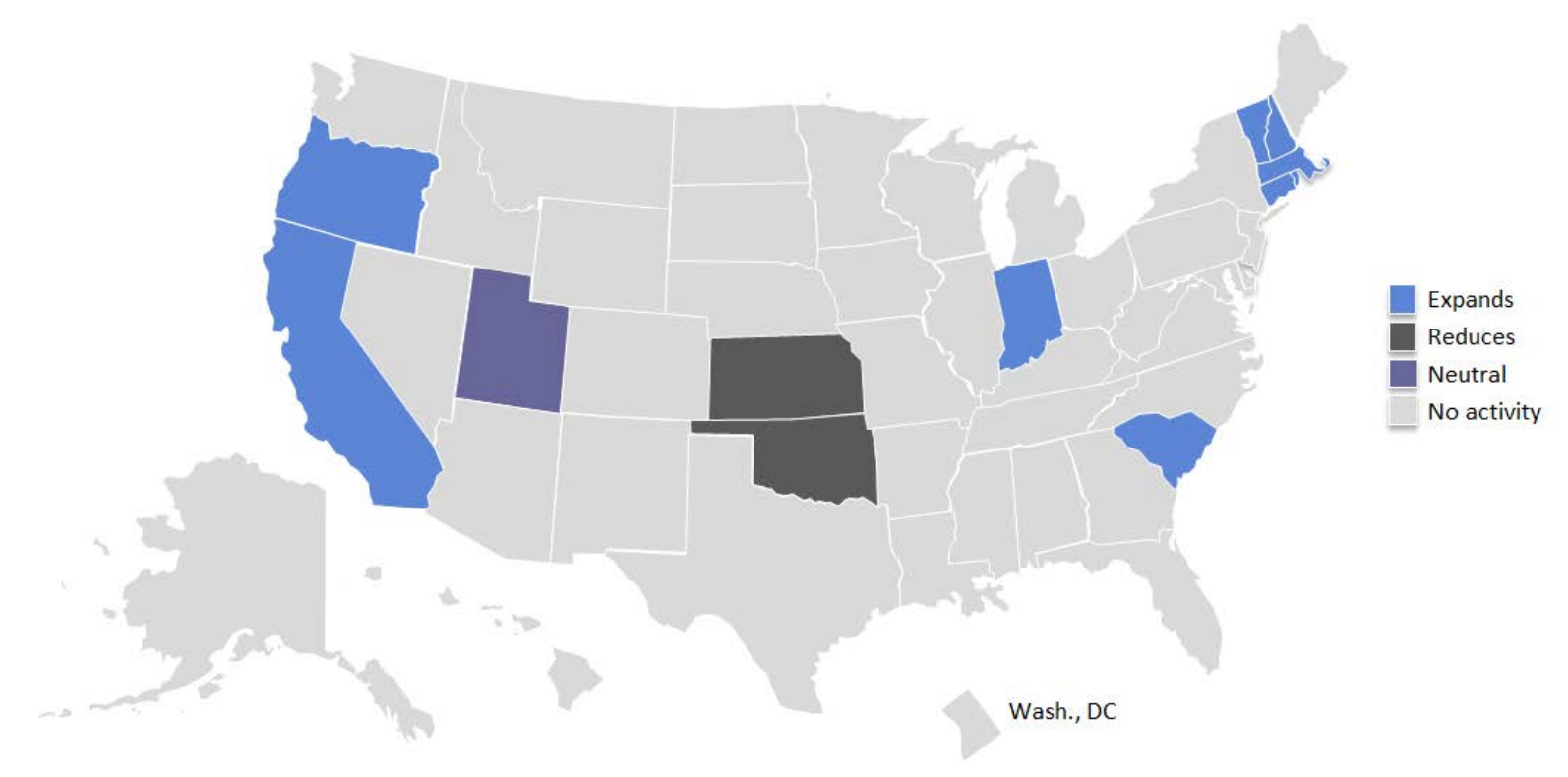

Figure 9. NEM-related bills enacted in 2014

Source: Durkay 2014

\subsection{Fixed and Standby Charges}

Utilities most commonly rely on volumetric charges to recover the majority of the costs of servicing residential customers. According to the U.S. Utility Rate Database, ${ }^{9}$ a storehouse of rate structure information from utilities in the United States containing more than 36,000 approved rates, the median monthly fixed charge for residential customers is $\$ 11.71$. Generally, these charges are intended to recover the costs of metering, billing, and payment processing, and are frequently also referred to as customer charges (Lazar 2014).

Proposed increases to fixed charges may apply only to net-metered customers or to all ratepayers in a given class (generally residential and small commercial customers, who typically do not pay demand charges). Additional fixed charges may be proportional to the size of the installed generator. Their main purpose is to allow the utility to recover the costs of maintaining and operating the grid. In 2013, the Arizona Corporation Commission approved a fixed monthly charge for residential customers of $\$ 0.70$ per kilowatt $(\mathrm{kW})$ of installed system capacity to compensate for costs shifted from net-metered customers to other utility customers in the territory of Arizona Public Service (APS) (Cardwell 2013; Martin 2013). A 6-kW distributed PV system could see a reduction in compensation levels of $4.1 \%$ in the first year of operation under the approved monthly fixed charge in APS's territory (Table 7).

An increase in fixed charges may be proposed in conjunction with a reduction in volumetric energy charges. The Wisconsin Public Service Commission (WPSC) approved in 2014 an increase in the monthly fee for Wisconsin Public Service (WPS) residential customers from $\$ 10.00$ to $\$ 19.00$, and a decrease in the price per $\mathrm{kWh}$ from roughly $\$ 0.111$ to $\$ 0.102$ (Content 2014). This lowers the value of the energy offset by distributed PV systems, contributing to the decrease in savings for PV customers. In the first year after the WPS rate change is implemented,

${ }^{9}$ http://en.openei.org/wiki/Utility_Rate_Database. 
a residential PV customer using a 6-kW system will see a savings decrease of $17.5 \%$ (Table 7). Smaller systems would see a higher percentage reduction in compensation levels because the charge does not take system size into account.

\section{Text Box 4: Grandfathering}

A difference between the fixed charges approved for APS and WPS is that in the case of the former, PV customers who installed their systems before the rate increase took effect were exempt. This is called grandfathering and does not apply in the case of WPS, where existing PV customers will see a reduction in the way their energy is compensated by the utility. Grandfathering is an important issue for existing PV customers and investors because the value of systems that have already been installed, and potentially securitized, could decrease from what was originally calculated under a different rate (see Section 4.3).

Standby charges are meant to cover the utility costs to ensure that individual PV customers have power available when their generation systems are not producing enough energy. Standby charges may be proportional to the customer's monthly peak demand. In 2011, Virginia's legislature approved a monthly standby charge of $\$ 4.19$ per $\mathrm{kW}$ of monthly peak demand, applicable to residential PV customers whose systems range between $10 \mathrm{~kW}$ and $20 \mathrm{~kW}$ of nameplate capacity (Passera 2011; Lillian 2011). In 2014, Central Maine Power proposed replacing the existing service charge with a flat monthly standby charge of $\$ 24.83$ for netmetered renewable energy generation systems, an increase of $\$ 15.47$ from the then-current rate of $\$ 9.36$. The standby charge would have been applicable regardless of system size to both existing and new systems (Gibson 2014), reducing the NEM compensation level for existing customers by $16.7 \%$ in its first year. Maine regulators approved increasing the monthly charge to $\$ 10.65$ (see Table 7).

\subsubsection{Fixed and Standby Charges Effects on Residential Solar PV Owners}

Table 7 summarizes five proposed rate design modifications that would reduce compensation levels for net-metered utility customers. A hypothetical 6-kW PV system installed in each utility's territory was used to model the impacts of the rate structure changes. ${ }^{10}$

The values in the columns describing proposed changes only reflect the differential between the proposed and current rates. For example, Idaho Power proposed increasing the monthly fixed charge for NEM customers from $\$ 5$ to $\$ 20.92$, a differential of $\$ 15.92$. The differential is expressed as a negative number because this is the value that the customer would see subtracted from the savings the customer's system would provide if no change was implemented. Similarly, the table shows the differential between proposed and existing volumetric retail rates, such as the 0.87 cents/kWh rate decrease approved for Wisconsin Public Service.

\footnotetext{
${ }^{10}$ Parameters and methodology to simulate such a system are described in the Appendix.
} 
Table 7. Proposed Rate Changes and the Impacts on a Hypothetical 6-kW System

\begin{tabular}{|c|c|c|c|c|c|c|c|c|c|}
\hline Utility (State) & $\begin{array}{l}\text { Request } \\
\text { Status }\end{array}$ & 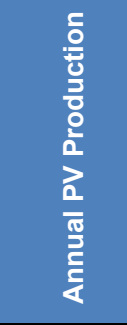 & 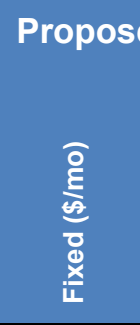 & 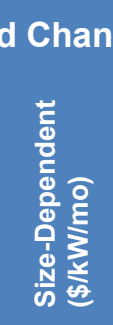 & 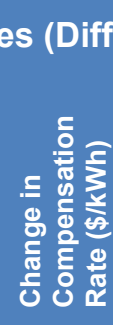 & 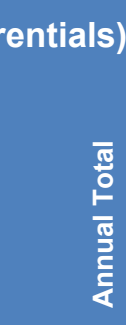 & 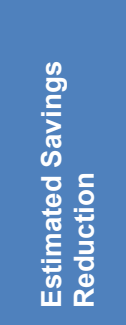 & 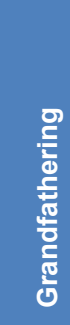 & 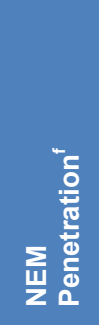 \\
\hline $\begin{array}{l}\text { Idaho Power } \\
\text { (ID) }\end{array}$ & Denied & $\$ 778$ & $-\$ 15.92$ & $-\$ 1.48$ & $-\$ 0.02$ & $-\$ 503$ & $-64.7 \%$ & No & $0.1 \%$ \\
\hline $\begin{array}{l}\text { Xcel Energy }{ }^{a} \\
\text { (CO) }\end{array}$ & $\begin{array}{l}\text { Separated } \\
\text { from docket }\end{array}$ & $\$ 952$ & & & $-\$ 0.06$ & $-\$ 535$ & $-56.2 \%$ & Yes & $1.2 \%$ \\
\hline WPS $^{b}(\mathrm{WI})$ & Approved $^{\mathrm{e}}$ & $\$ 994$ & $-\$ 9.00$ & & $-\$ 0.01$ & $-\$ 174$ & $-17.5 \%$ & No & $0.1 \%$ \\
\hline $\operatorname{APS}^{c}(A Z)$ & $\begin{array}{l}\text { Approved } \\
\text { as amended }\end{array}$ & $\$ 1,226$ & & $-\$ 0.70$ & & $-\$ 50$ & $-4.1 \%$ & Yes & $2.0 \%$ \\
\hline $\mathrm{CMP}^{\mathrm{d}}(\mathrm{ME})$ & $\begin{array}{l}\$ 10.65 \text { fixed } \\
\text { charge } \\
\text { approved }\end{array}$ & $\$ 1,109$ & $-\$ 15.47$ & & & $-\$ 186$ & $-16.7 \%$ & No & $N / A^{g}$ \\
\hline
\end{tabular}

See Appendix for detailed parameters and assumptions. Annual PV production assumes that every kWh is compensated at retail prices either because it is consumed instantly or net-metered, as opposed to compensated at wholesale prices or forfeited at the end of the NEM cycle. The table is meant for illustrative purposes only and does not necessarily reflect the loss in savings that customers for each of these utilities would experience. Actual values ultimately depend on consumption profiles and other parameters specific to each customer.

${ }^{a}$ Xcel Energy submitted its estimate of the value of distributed PV but did not propose any immediate changes.

${ }^{\mathrm{b}}$ Wisconsin Public Service Corp.

${ }^{\mathrm{c}}$ Arizona Public Service

${ }^{d}$ Central Maine Power Company

${ }^{\mathrm{e}} \mathrm{A}$ judge in Wisconsin remanded two of the provisions approved (maximum size and netting period) back to the state regulators (Content, 2015). This decision does not affect this analysis.

${ }^{f}$ Ratio of net-metered customers to total customers at the end of 2013. Source: EIA 2015b.

${ }^{g}$ Not reported.

\subsection{Minimum Bills}

Minimum bill requirements are intended to ensure that all customers pay their share toward the costs of maintaining the electric grid, even when their net consumption is close to zero or negative for a given bill cycle. This mechanism works by requiring utility customers to pay their bill as normally calculated or a minimum monthly charge, whichever is higher.

California's Assembly Bill 327, enacted in 2013, authorizes the state's Public Utilities Commission to approve requests from utilities to impose fixed charges or minimum bills of up to $\$ 10.00$ per month to residential customers. In Massachusetts, a bill authorizing minimum bills died in the legislature in 2014 (Davis 2014).

Fixed charges are more likely to increase the cost of electricity than minimum bills ${ }^{11}$ for PV customers because fixed charges are assessed regardless of consumption level for a given billing

${ }^{11}$ Assuming fixed charges and minimum bills are assessed at a similar level. 
cycle. Minimum bills, on the other hand, are only triggered in cycles when net consumption is close to zero or negative. It has been estimated that a $6.3-\mathrm{kW}$ system installed in Massachusetts could see a reduction in savings of $8.5 \%$ if a $\$ 10.00$ per month fixed charge was imposed in the state, as compared to $2.8 \%$ under a $\$ 10.00$ minimum bill (Cornfeld and Kann 2014). ${ }^{12}$

\section{Table 8. Comparison Between Minimum Bills and Fixed Charges in Massachusetts (NStar utility territory)}

\begin{tabular}{|llll|} 
Charge & $\begin{array}{l}\text { System Size } \\
\text { Modeled }\end{array}$ & Charge Amount & $\begin{array}{l}\text { Estimated } \\
\text { Savings } \\
\text { Reduction }\end{array}$ \\
\hline Minimum Bill & $6.3 \mathrm{~kW}$ & $\$ 10$, monthly & $2.8 \%$ \\
\hline Fixed Charge & $6.3 \mathrm{~kW}$ & $\$ 10$, monthly & $8.5 \%$ \\
\hline
\end{tabular}

Source: Cornfeld and Kann 2014

\subsection{Demand Charges}

Rates based on volumetric charges may make it more difficult for utilities to recover capacity costs from NEM customers (see Text Box 2). Demand-based rates, on the other hand, assess a charge each billing cycle based on customer peak demand and have been most commonly applied to larger commercial and industrial customers (Hledik 2014). NEM offsets volumetric use and therefore offers greater economic advantages to PV customers under usage-based rate schedules.

In 2013, the Arizona Public Service (APS) asked state regulators for authorization to either bill new residential net-metered customers under a rate schedule that includes demand charges (specifically schedule ECT-2) or purchase all of their generation at a rate based on wholesale rates $^{13}$. A residential 7-kW system under APS's existing ECT-2 demand-based rate could see a cut in electricity savings of $48 \%$ over its economic life (Kennerly et al. 2014).

\subsection{Wholesale Rates}

Most current NEM programs require the utility to credit every kWh exported by net-metered systems at the retail rate. As mentioned above, one of the changes proposed by APS in 2013 was to purchase all of the generation from residential net-metered customers' wholesale rates. This option would compensate generation independently from consumption, in stark contrast with NEM. It has been calculated that APS's proposal would represent a decrease of approximately $70 \%$ from NEM compensation levels (ASU-EPIC 2013). In 2013, Xcel Energy in Colorado submitted testimony showing its estimated value of distributed PV generation, which was roughly $\$ 0.06$ per $\mathrm{kWh}$ lower than the retail rate (Hyde 2013). A 6-kW system compensated at that level could see a reduction in savings of $56.2 \%$ in the first year after the implementation of the new rate (Table 7).

\footnotetext{
${ }^{12}$ In Massachusetts, net metering credits can be used to offset monthly customer charges, making it possible for PV customers to pay $\$ 0$ in a given billing cycle.

${ }^{13}$ Existing residential PV customers would have been grandfathered, Docket No. E-01345-13-0248.
} 


\subsection{Value of Solar Tariff}

Under a value of solar (VOS) tariff, PV customers are credited for the energy they export to the grid at a rate that includes the cost for the utility to generate and deliver a unit of renewable energy to the point of consumption. The calculation also includes the value assigned to the environmental and renewable attributes of solar generation. A VOS tariff may compensate generation separately from consumption (Rábago 2013).

Calculating the VOS tariff involves selecting the relevant benefits and costs of solar generation and calculating their monetary value. The process of designing a VOS tariff can be contentious because some stakeholders may disagree on what categories of value may be considered relevant or on the methodology to value each category. Wind, biomass, combined heat and power (CHP), fuel cells, and other distributed energy resources may require their own specific calculations because they offer different utility value profiles than distributed solar (Taylor et al. 2015), which could result in an expensive and long process.

A potential concern with this type of compensation mechanism is its variability. One of the main factors in the VOS calculation is the projected price of natural gas, which may vary considerably from year to year, represented in VOS calculations as avoided fuel cost (Figure 10). In Austin, yearly rate adjustments have created significant uncertainty for existing PV customers and made it more difficult for prospective customers to decide whether to invest in a PV system (White 2014). The VOS tariff implemented in Minnesota avoids this problem by locking the value of solar - adjusted for inflation - for the duration of the contract (Minnesota Office of the Revisor of Statutes 2013).

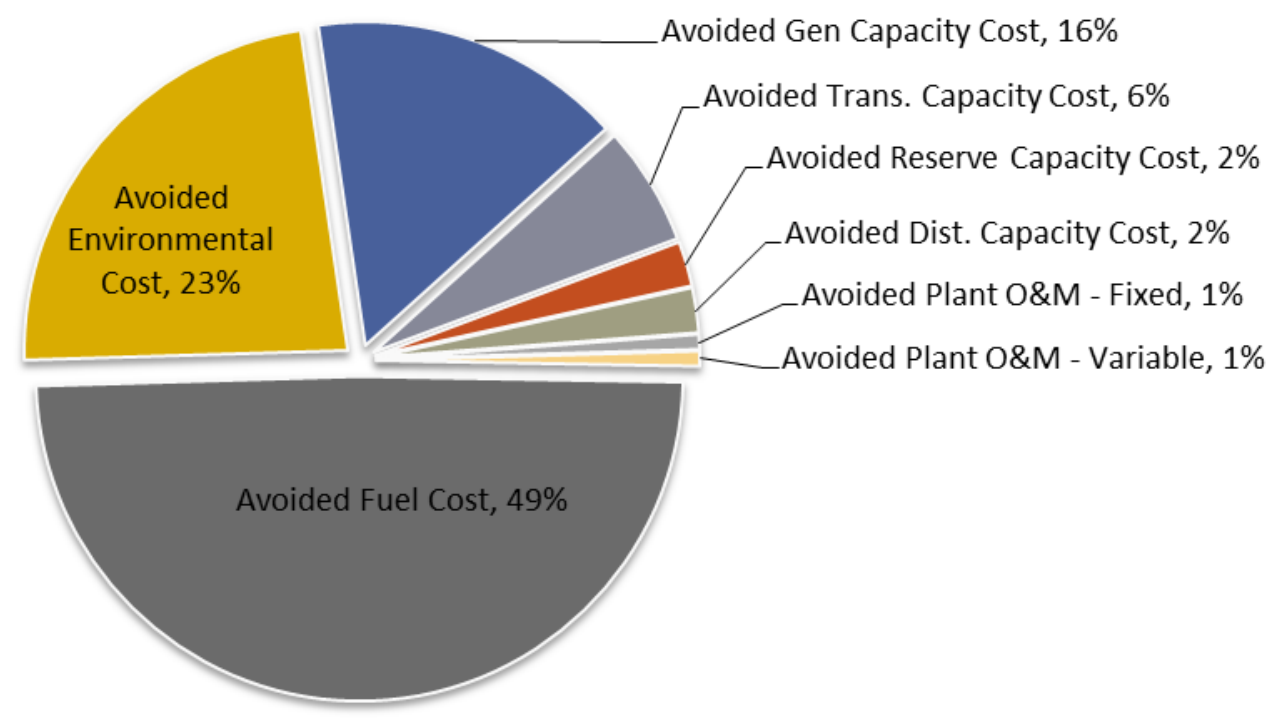

Figure 10. Relative weights for all the components in a 25-year levelized VOS calculation developed by the Minnesota Department of Commerce for illustrative purposes.

Source: Minnesota Department of Commerce 2014

With all other variables held constant, the effect of a fixed VOS tariff, such as Minnesota's, on the economics of distributed PV systems as compared to net metering depends primarily on the initial value of solar per $\mathrm{kWh}$ and the rate at which retail electricity prices increase during the life 
of the system. In the case of a hypothetical 6-kW system installed in Minnesota, ${ }^{14}$ an initial VOS rate that is higher than the retail price of electricity results in a higher net present value (NPV) than net metering, as expected. If retail electricity prices rise at a rate higher than inflation, the NPV of a system under VOS will be lower than net metering because NEM compensation is equal to retail prices and VOS is fixed over the life of the system (Figure 11).

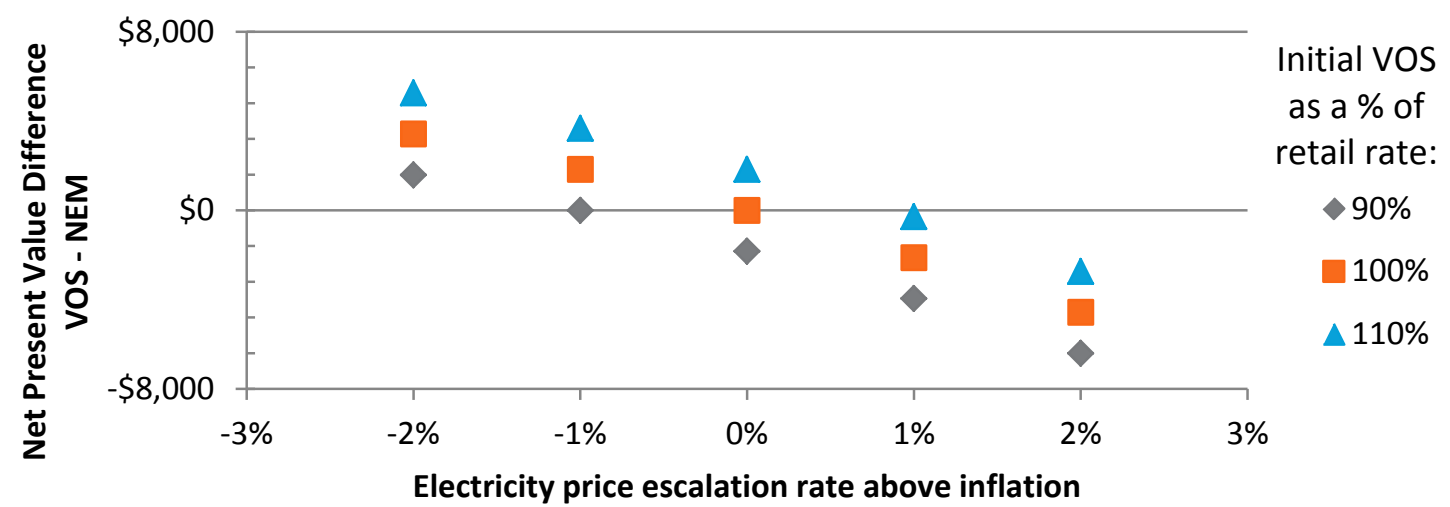

Figure 11. Comparison between the net present value of VOS and NEM under different electricity price escalation rates and initial value of solar rate as a percentage of retail rate

Participation in a VOS tariff program may have tax implications that could severely undermine the economics of residential solar systems. First, it may render PV customers ineligible for the federal investment tax credit (ITC), which currently equals $30 \%$ of the cost of systems installed before the end of 2016. Second, revenues received under the VOS tariff may qualify as taxable income (Hines 2015). A VOS tariff participant in Austin requested an Internal Revenue Service (IRS) review of the tax implications for PV customers compensated through Austin Energy's VOS rate (Trabish 2014). As of August 22, 2015, the IRS has not clarified its position on the matter.

\section{Text Box 5: VOS Tariff Implementations in the United States}

Austin Energy, a municipal utility in Texas, was the first utility to design a VOS tariff. As of August 22, 2015, Minnesota is the only state with a VOS tariff. An important difference between Minnesota and Austin is that in the former, VOS rates are locked in for individual customers during the 20-year duration of the contract (Minnesota Office of the Revisor of Statutes 2013). Also, utilities in Minnesota can decide whether to use the VOS tariff or NEM. In Austin, that decision is left to individual PV customers and their compensation rate may be adjusted yearly by regulators (Farrell 2014).

The Minnesota Public Utilities Commission has not calculated the official VOS rate because no utility has yet chosen to use it. In its testimony during the proceedings, Xcel Energy estimated a value of solar rate of $\$ 0.145 / \mathrm{kWh}$, compared to a $\$ 0.1285 / \mathrm{kWh}$ statewide average rate for residential customers (Xcel Energy 2014).

\footnotetext{
${ }^{14}$ Assumes a capacity factor of $15 \%$, a discount rate of $2 \%$, an installation cost of $\$ 3.12 / \mathrm{W}$, and that under net metering all the energy output is compensated at retail rates. Uses a retail rate value of $\$ 0.1285 / \mathrm{kWh}$ and a VOS of $\$ 0.145 / \mathrm{kWh}$, as calculated by Xcel Energy (2014).
} 


\section{Reform Options that Preserve Value for Stakeholders}

The effects of net-metered PV on utility revenues and non-PV customers are smaller at lower penetration levels (CPUC 2013; Satchwell 2014). However, increasing levels of distributed PV could affect utilities in ways that may not have been foreseen when current compensation mechanisms were put in place. In response, utilities are using different strategies aimed at adapting to a changing environment and protecting their revenues. In certain instances, legislative reforms and rate design changes create uncertainty for the PV industry and PV customers. Transitioning from current policies in a deliberate and transparent way and in the right timeframes could help stakeholders adapt to new levels of distributed solar penetration and preserve economic value.

The strategies discussed in this section are not all equally effective at protecting stakeholder value, and they all carry their own tradeoffs. For example, increased fixed charges are likely to reduce value for net-metered customers and reduce returns for stakeholders. The most effective combination of strategies will depend on current market conditions and stakeholder goals.

Pressure to change existing conditions may build up when the interests of one or more stakeholders are severely affected. Implementing options that protect the interests of all stakeholders, as much as possible, could bring the additional benefit of longer term stability.

The benefits and costs of current policies may shift as technology and market conditions evolve. This creates the necessity to consider policy options able to adapt and evolve as conditions change. PV costs and penetration are two of the variables that could be potentially used to select the appropriate combination of value-preserving options. At low levels of penetration, net metering does not pose a threat to any stakeholder. Figure 12 shows net metering as an option for scenarios with low levels of PV penetration. As the cost of PV falls and penetration levels rise, other options, such as the ones presented in this section, could be used to balance the interests of the involved stakeholders. In general terms, higher levels of PV penetration could require options that increase the sophistication of the system. For example, unbundling the price of utility service components would represent a higher level of system sophistication than fixed monthly charges, mainly because the latter do not require the use of advanced metering capabilities and billing would be simpler.

This section presents DG compensation options that can be implemented independently or in combination to provide stakeholders with certainty and preserve stakeholder value. 


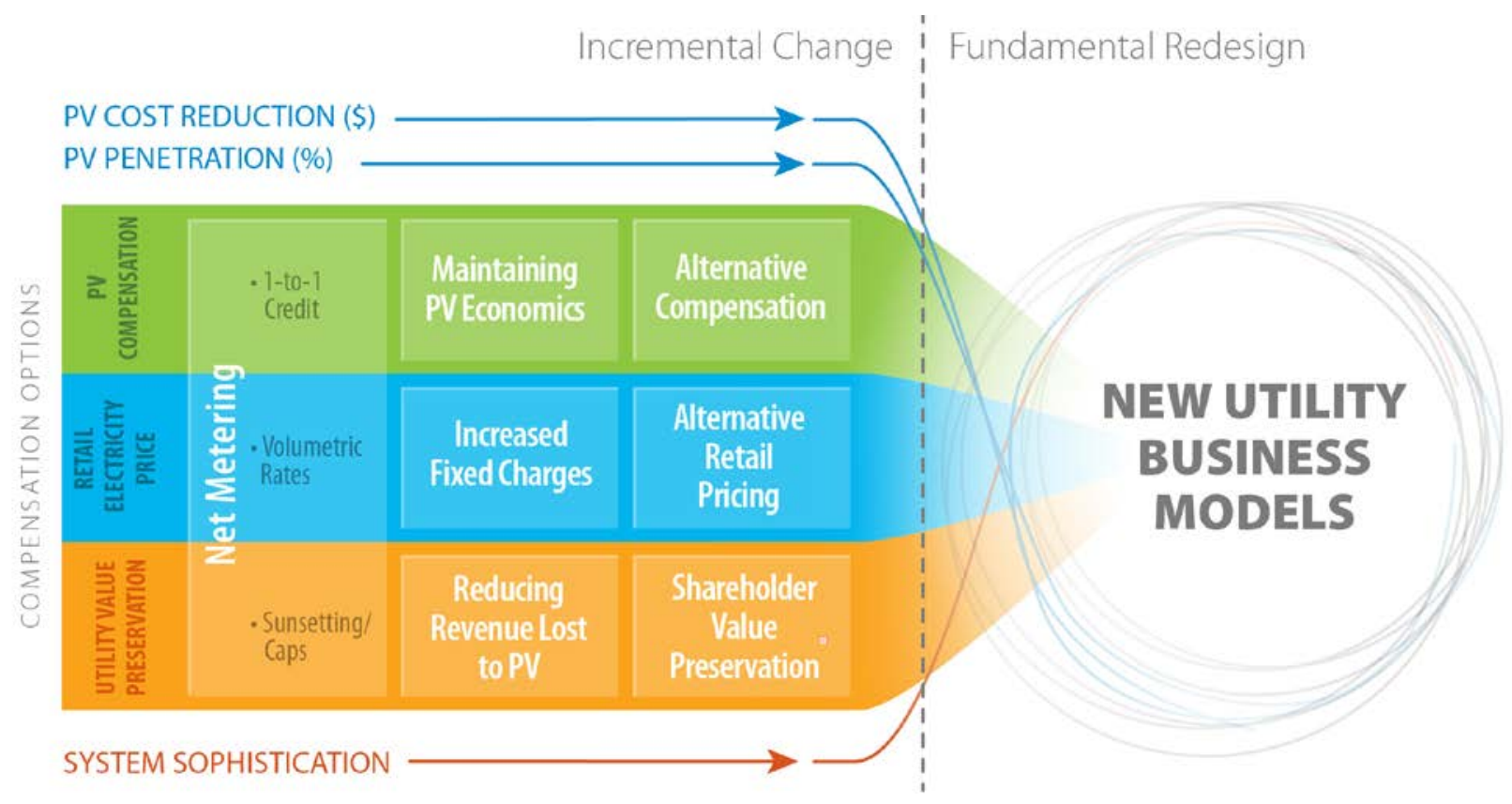

Figure 12. Compensation options grouped by category and level of complexity

\subsection{PV Generation Compensation Options}

\subsubsection{Declining Levels of Compensation}

At the point when the effects of cost-shifting become relevant, as evaluated by regulators, compensation for new PV customers could be adjusted based on indicators such as the cost of installed distributed PV and electricity rates in jurisdictions and utilities where rebates have been phased out. The goal would be to keep distributed PV compensation at a relatively steady level that promotes adoption and avoids overcompensation.

\section{Alternative Compensation}

- Distributed LMP

- Value of solar tariff

- Declining compensation 


\section{Text Box 6: PV Pricing Trends}

Technological innovation has historically driven the costs of solar PV systems down and continues to do so. Falling PV system costs reduce the industry's reliance on policy-based incentives and compensation, reducing in turn the regulatory risk presented by potential changes in NEM laws and regulations. Residential- and commercial-scale PV system prices have declined by about $6 \%$ to $7 \%$ per year on average between 1998 and 2013. Between 2012 and 2013, the decline in prices was between $12 \%$ and $15 \%$. Analysts expect PV pricing to continue to decrease in the long term (Feldman et al. 2014). The U.S. Department of Energy's SunShot initiative has a goal to decrease the non-hardware costs of installing solar PV systems, such as permitting and financing, by $80 \%$ (from $\$ 2.50 / \mathrm{W}_{\mathrm{DC}}$ to $\$ 0.50 / \mathrm{W}_{\mathrm{DC}}$ ) by 2020 (DOE n.d.).

\subsubsection{New Distributed Generation Compensation Options}

Under net metering, every $\mathrm{kWh}$ produced by distributed systems is credited with one $\mathrm{kWh}$. In areas where utility-administered incentives, such as rebates, have been phased out, PV customers could be compensated at a rate between wholesale and retail. Compensation step-downs could be set as a function of relevant variables, such as PV costs and retail rates. Scheduled declines like step-downs based on pre-determined dates may not necessarily align with market conditions and unfairly affect one party over the other. Declines in compensation based on objective and transparent information could help minimize the impact of cost-shifting and facilitate a fair rate of return for PV customers.

Other mechanisms to compensate DG have been proposed, such as the VOS tariff described in Section 3.5. A more sophisticated compensation approach is the distributed locational marginal pricing (DLMP), an approach that is analogous to the way generation is compensated in wholesale competitive markets for electricity. DLMP would price DG according to location and real-time demand and congestion conditions. The primary goal of these mechanisms is to more accurately compensate DG for its attributes and encourage its use and deployment in ways and locations that support grid reliability.

\section{Text Box 7: Grid Support}

Distributed solar could support grid reliability by providing services such as reactive power regulation and, in cases of high penetration levels, smoother ramping rates (McLaren 2014). Economic signals could encourage PV customers to provide such services when needed by the utility.

Economic signals could also encourage the location and configuration of PV systems in ways that benefit grid operation. For example, price signals could encourage prospective PV owners to install their systems facing west to support generation in the late afternoon, when demand peaks, or in distribution lines that have adequate carrying capacity (Edge et al. 2014).

Experience with these compensation mechanisms is still too limited to offer a clear understanding of their effects on PV system economics. Variable compensation mechanisms could increase volatility and revenue uncertainty for PV customers, which in turn could discourage PV adoption. 


\subsubsection{Grandfathering and Long-Term Contracts}

Adjustments in regulation and compensation levels may be necessary to accommodate an evolving market where the economics and impacts of distributed solar are constantly changing. The solar industry can plan for this changing environment. However, systems that are already installed are vulnerable when changes in policies do not protect their value.

Grandfathering provisions exempt existing customer generators from changes in NEM policies or compensation levels that could affect their future cash flows. Clear grandfathering provisions written into policies as they change could help preserve value for existing PV customers. These provisions are important because the calculation of solar PV benefits for potential PV customers is based on policies current at the time the lease or sale contract is signed. Uncertainty regarding solar PV economics could send a negative signal to potential solar adopters and severely affect adoption rates. This, in turn, can negatively affect the solar industry as a whole and could lead to economic and job losses.

Currently, lack of performance data makes it difficult to assess the effect of the variability of alternative compensation mechanisms (described in Section 4.1.2) on PV system economics. The experience with solar renewable energy credits (SRECs) (see Figure 13), which have been used since at least 2007 (Hart 2010), demonstrates that the effects of volatility include increases in the cost of solar financing and uncompetitive market outcomes (Felder and Loxley 2011). Incentives and long-term contracts (during which compensation levels would not change) could promote revenue certainty for PV customers. 


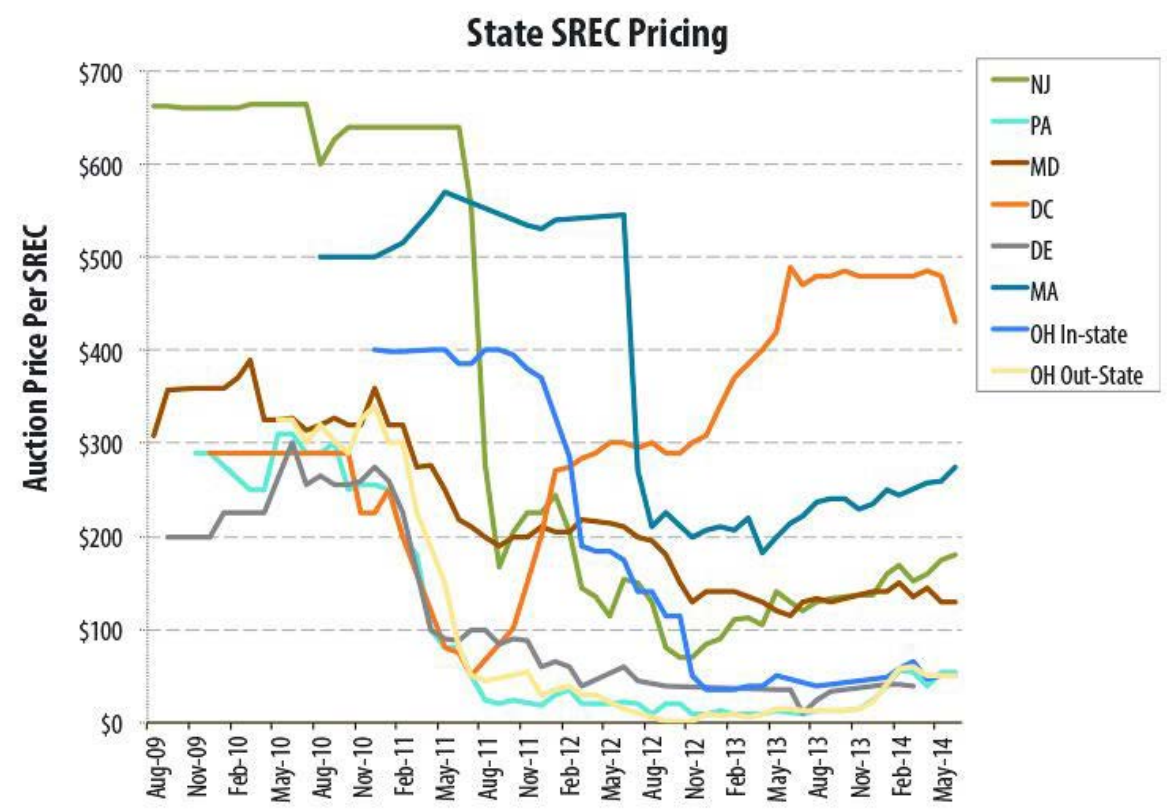

Figure 13. Historical auction SREC prices

Source: EERE 2015

\subsection{Retail Electricity Pricing Options}

\subsubsection{Higher Fixed Monthly Charges}

Utilities are increasingly filing for higher fixed monthly charges to compensate for the effects of growing levels of net-metered PV. However, increasing fixed charges can reduce the value of PV systems because fixed charges reduce the savings for PV customers (see Table 7 in Section 3). Increased fixed charges are disadvantageous for smaller consumers and discourage energy conservation, ${ }^{15}$ particularly when coupled with lower per-kWh charges (Lazar 2014). In the long term, more consumption could increase infrastructure and generation needs, adding to the overall cost of service.

High customer fixed charges could exacerbate the loss of returns for utility shareholders. Although fixed charges may help reduce the economic impact of distributed PV resulting from reliance on volumetric energy charges in the short term, a higher fixed charge sends an economic signal to customers to disconnect from the grid (Satchwell et al. 2014; Byrd et al. 2014). The decreasing costs of both PV and electricity storage technologies increase the possibility of customers reducing their reliance on grid energy and services (see Text Box 8). Losing even a small fraction of retail energy sales could have a large impact on utility economics (Bronski et al. 2015).

Minimum bills address revenue adequacy by guaranteeing the utility a minimum annual revenue from each customer, regardless of their usage level (Lazar 2014). Minimum bills do not reduce savings for PV customers as much as fixed charges of the same amount because they are not assessed when consumption reaches a minimum threshold (see Table 8 in Section 3.2).

\footnotetext{
${ }^{15}$ Fixed charges are fixed not only month to month for each customer, regardless of actual consumption, but also across each customer class. This means that fixed charges represent a higher proportion of the total electricity bill for low-use customers compared to high-use customers within the same class.
} 


\section{Text Box 8: Energy Storage}

Net-metered systems need the grid to export surplus energy when it is not instantaneously consumed onsite and to provide energy when the system is not producing enough. Energy storage reduces or eliminates that need. The costs of both solar PV and energy storage systems show a downward trend that is expected to continue (Feldman et al. 2014; Makhyoun and Taylor 2014). Battery costs for electric vehicles have decreased much faster than expected, reaching in 2014 the level that the International Energy Agency predicted they would reach in 2020 (Smith 2015). As technology costs continue to decrease, the levelized cost of systems that combine PV and storage will intersect with the cost of electric energy delivered by utilities, reducing or eliminating the need to exchange energy with the grid, at least for customers who can find a way to finance the upfront costs of the technology.

\subsubsection{Alternative Retail Pricing Mechanisms}

Volumetric energy rates may be inadequate to recover the capacity costs of servicing PV customers whose net energy consumption is close to zero (see Text Box 2). Single fixed charges do not fully and accurately reflect the value of the services provided by the utility, which include the energy provided and the maintenance of the distribution network, because each customer has a unique load profile (Overcast 2015). More accurate retail pricing could help utilities recover the costs of servicing their customers, even those with distributed energy resources, without discouraging the adoption of new technologies (Glick et al. 2014).

Utilities must have enough capacity available to service their customers' peak demand. Demand charges based on

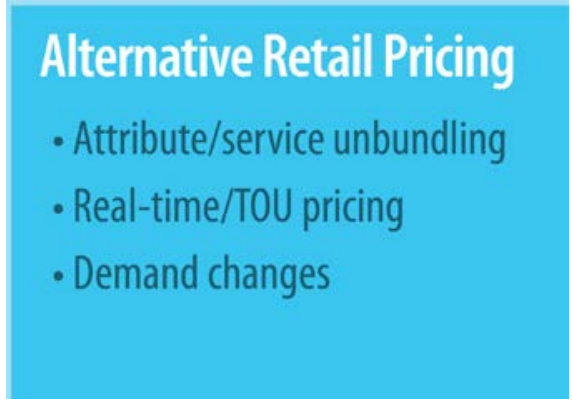
the maximum demand could be an efficient method to recover capacity costs (Overcast 2015). However, demand charges could encourage the use of solar-plus-battery systems to reduce peak demand, which in turn could reduce customers' reliance on the grid and exacerbate cost recovery issues for utilities (Trabish 2015; Bronski et al. 2015).

The goal of time-of-use rates and real-time retail pricing of electricity is to send price signals that reflect more accurately the changes in generation costs as demand changes during the day and across seasons. Similarly, unbundling the components included in the services that utilities provide has the goal of reflecting more accurately the costs of supplying customers with energy and grid services. Unbundling rates could help utilities recover costs from services that PV customers use but may not pay for under a traditional, volumetric rate.

When alternative retail pricing mechanisms are used, such as time-of-use rates, bill credits may be calculated by multiplying the energy exported to the grid (in $\mathrm{kWh}$ ) by the energy component of the tariff valid at the time of generation. Alternatively, the electricity buying and selling transactions could be completely separated. In that case, different compensation and retail pricing mechanisms could be used. 


\subsubsection{Paying for the Clean Attributes of PV Generation}

Compensating PV customers for the clean attributes of the energy generated through solar PV imposes costs to the electric system. In renewable portfolio standards (RPS), these costs are typically distributed among ratepayers through a surcharge on customer bills. Regulators could look into whether cost-shifting induced by NEM is occurring, at least partially, because the costs of paying for the clean attributes of PV are transferred to non-participants. If that is the case, regulators could create a mechanism that acknowledges the benefits of paying for the clean attributes of renewable energy and formalizes the collection of revenue from non-participants.

\subsection{Protecting Utilities' Revenue Adequacy}

Net metering does not represent a risk for utilities at lower levels of distributed PV penetration. The effects of net metering on utilities' revenues and shareholder revenue generally may grow in proportion to distributed solar penetration levels (see Figure 5 and Figure 6 in Section 2.2.1). ${ }^{16}$

\subsubsection{Net Metering Sunsetting Provisions and Caps}

Policies that include sunset or adjustment provisions tied to timelines or penetration levels could provide long-term certainty for utilities. As of August 2014, 25 of the 43 states with net metering policies had peak or capacity caps, 15 and the District of Columbia had no restriction, and 3 had notification policies (Heeter et al. 2014).

Utilities could commit to refrain from proposing legislation or rates that reduce compensation levels in exchange for the added certainty. The agreement described in the text box below offers an example of how sunsetting provisions may work.

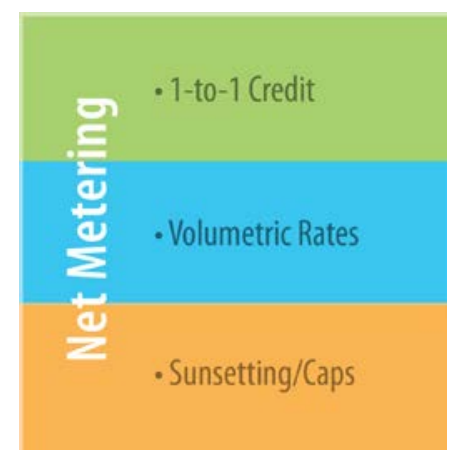

\section{Text Box 9: South Carolina's Multi-Stakeholder Agreement}

In 2014, utilities, environmental organizations, and solar advocacy groups in South Carolina signed an agreement to support distributed solar and balance the interests of all stakeholders.

Under the agreement, the signing utilities will continue net metering at least until 2025 and provide incentives in a manner that gives "price certainty to the customer-generator over a defined term" (ORS 2014). Utilities also agreed not to file for rate modifications that would undermine the spirit of the agreement (e.g., increased fixed fees) until it expires at the end of 2020. Importantly, the agreement also includes a methodology for utilities to recover lost revenue from net metering.

A revision of the program is scheduled for 2020 and sunset provisions give certainty to utilities that net metering provisions will be revisited in the future. Customers and investors get longer-term cash flow certainty, and the rest of the solar industry knows what incentives and rate structures will look like for the next six years (Swartz 2014; ORS 2014).

\footnotetext{
${ }^{16} \mathrm{DG}$ is only one of several factors that can reduce revenues for utilities. Others, such as energy efficiency and storage, are not covered in this report.
} 


\subsubsection{Reducing Utility Revenue Lost to Distributed PV}

Strategies that protect utility value can be considered when levels of distributed PV penetration reach previously established thresholds. Specific penetration trigger levels could be calibrated depending on the type of utility, rate structure, load growth and other factors.

Potential strategies to reduce utility revenue lost to distributed PV include a shareholder incentive based on performance metrics (such as PV penetration goals) and ownership of distributed PV systems on either side of the meter.

\section{Text Box 10: Examples of Utility Ownership of Distributed PV}

The goals of distributed PV utility ownership include gaining expertise in owning and operating distributed PV, locating distributed PV systems where they could support grid operations more appropriately, and testing advanced functions such as voltage support (Kauffman 2015; Duke Energy, n.d.)

Duke Energy in North Carolina owns and maintains solar systems located on the roofs of large commercial or industrial buildings and residential rooftops. Participating customers do not incur any costs and receive annual rental fees. Duke Energy maintains ownership of the electricity (Duke Energy, n.d.).

Public Service Electric and Gas (PSE\&G) has installed more than 100 MW of PV in its territory, including DG systems in public and private properties (PSE\&G 2015).

In December 2014, the Arizona Corporation Commission approved Tucson Electric's program for 500 to 600 customers to install PV systems owned by the utility. The participants will pay an upfront fee of $\$ 250$ and a fixed monthly payment based on their average monthly usage (Kauffman 2015).

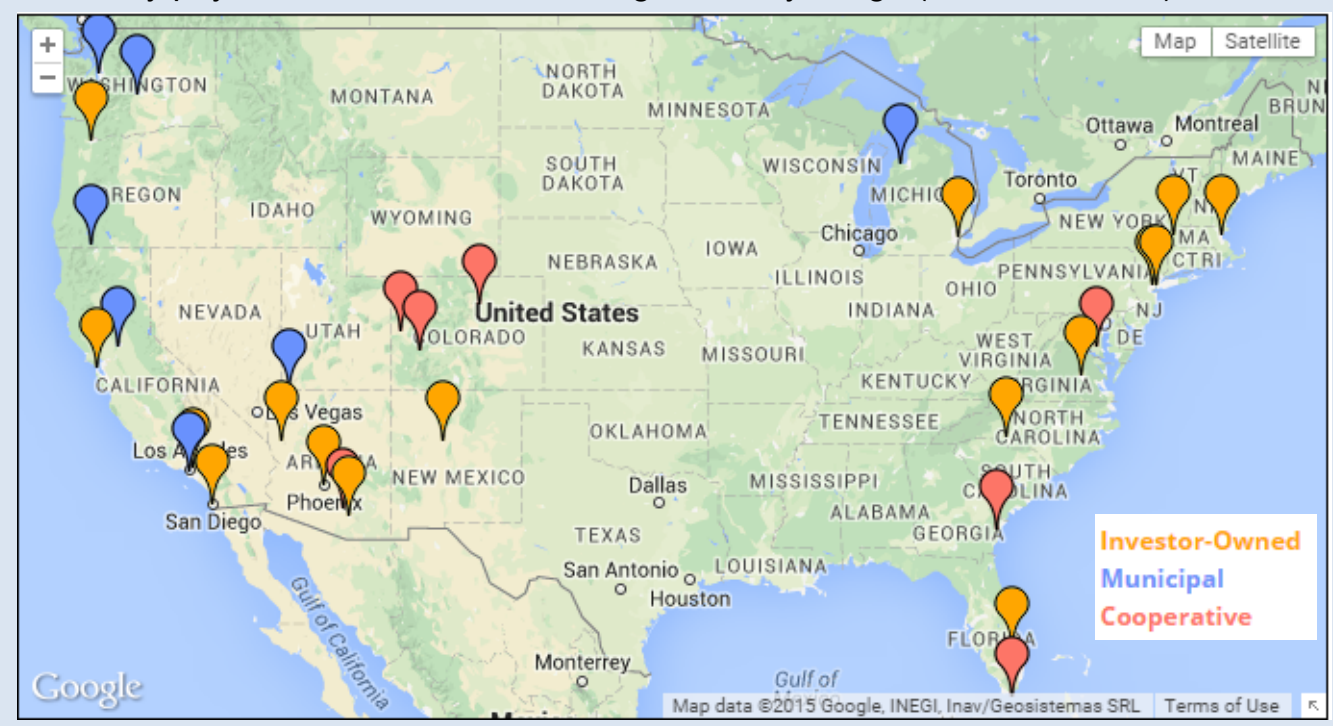

Figure 14. Location of utility-owned PV systems by utility type

Source: Solar Electric Power Association. 


\subsubsection{Preserving Shareholder Value}

Utility customer PV adoption may defer investment on generation, leading to a reduction in utility shareholder returns. The strategies that can help preserve value for utility shareholders include revenue-per-customer (RPC) decoupling and other regulated mechanisms for utilities to recover lost revenue, such as performance incentives and lost revenue adjustment mechanisms (LRAM).

The goal of decoupling is to ensure the recovery of a

Shareholder Value Preservation - Revenue decoupling - Lost revenue adjustment - Rate case frequency defined amount of revenue regardless of electricity sales in a given period. RPC is the most common decoupling method used. RPC uses the number of customers served as the driver for computing allowed revenues between rate cases. Rates are adjusted up or down, typically once a year, to meet allowed revenues at the end of the adjustment period (RAP 2011).

Financial incentives aim at compensating utilities for the shareholder returns lost due to the deferral of investments in utility generation.

An LRAM is an alternative to decoupling that allows a utility to recover revenues that are reduced as a result of a specific program, such as energy efficiency or net metering programs, as evaluated by a third party. LRAM only covers the portion of the lost revenues needed to cover the utility's existing fixed costs; variable costs, such as fuel, are not covered by LRAM. Currently, 17 states have LRAM policies (Indiana Energy Association 2015; ACEEE 2015).

Generally, utilities' costs grow faster than their revenues. Distributed PV adoption can exacerbate ROE reductions due to the lag between filing of rate cases and implementation of new rates. Increasing the rate case frequency, or reducing regulatory lag, can also have a positive impact on shareholder ROE (Satchwell et al. 2014). ${ }^{17}$

\subsection{New Utility and Business Regulatory Models}

New utility business and regulatory models are featured at the top of Figure 12. These models change the relationship between stakeholders at the distribution level and represent an important departure from the way the distribution grid in general has been regulated for decades.

A broad range of recent literature reflects on the role that utilities and regulators will play in a changing electricity industry (see Bibliography). The authors generally take a long-term, holistic

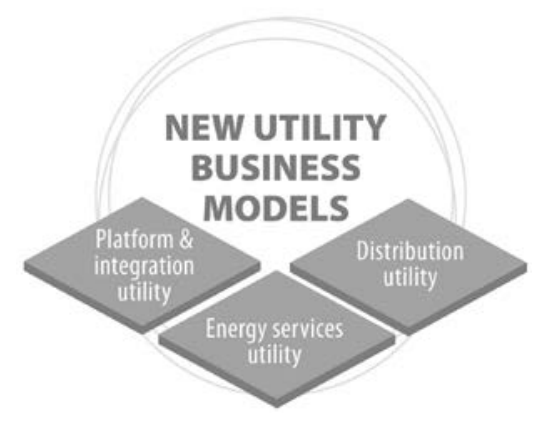
perspective of the electric system and describe potential changes to the operation and regulation of the distribution system. The issues considered include the integration of variable renewable energy into the distribution network, the viability of the current utility business model in the face of technological disruption, and the role of regulators in facilitating a potential transition to a different model.

\footnotetext{
${ }^{17}$ More in-depth discussions about comprehensive strategies that utilities could follow to mitigate the effects of customer-side energy technologies on their business models can be found in the bibliography section.
} 
The number of utility business models is not defined and the business models are not uniformly named. The list of utility business models presented at the top of Figure 12 is not intended to be comprehensive. In several of these new models, the utility's profit is not directly tied to energy sales and therefore is indifferent to increases in energy efficiency and distributed generation levels.

The Distribution Utility is sometimes referred to as wires-only because it does not own generation assets, only the distribution network. This model may still be vulnerable to low demand growth rates because the bulk of distribution charges are typically tied to sales (Faruqui 2014). The Energy Services Utility focuses on selling customers lowest-cost end-use services such as cooling, heat, and light. Additionally, this type of utility could assist its customers to use energy more efficiently and provide on-bill financing (Fox-Penner 2014). Finally, the Platform and Integration Utility owns and operates the distribution network in a way that enables the efficient and cost-effective integration of distributed energy resources. This utility is responsible for creating and maintaining the infrastructure, markets, and information exchange systems that transparently and efficiently integrate and compensate distributed resources.

\section{Text Box 11: Reforming the Energy Vision}

The state of New York is forging a unique path in the United States through its Reforming the Energy Vision (REV) initiative launched by the state's Public Service Commission. The REV initiative calls for utilities to act as platform providers. This includes owning and maintaining the distribution system as well as creating "markets, tariffs, and operational systems" to enable a wider deployment of DG, energy storage, and demand response technologies. Ultimately, the new model would unbundle the integrated price of electricity and replace NEM with market mechanisms that would act as both incentives and compensation for the environmental and system benefits that distributed PV systems bring to the grid (NYDPS 2014).

Although it would be premature to predict what role NEM policies will play under these new models, the trend seems to be to place the emphasis on market forces and tariff-based incentives, instead of NEM, to promote distributed energy resources and more accurately assign a cost to PV and other forms of distributed generation.

More information about new utility models can be found in the sources listed in the Bibliography section. 


\section{Conclusions}

Changing circumstances, such as increasing DG penetration levels and decreasing solar costs, have prompted utilities, regulators, and other stakeholders to examine the current mechanisms used to compensate owners of distributed PV systems. Two areas that have experienced increased activity are rate redesign and legislative reforms. Even though DG compensation levels remain stable nationwide, uncertainty can have negative effects on the rate of expansion of the solar industry. Additionally, existing owners of distributed PV systems are vulnerable to rate changes that do not include grandfathering exemptions.

It may prove important to review and possible recalibrate DG compensation policies as markets continue to evolve, and if an unbiased cost-benefit analysis concludes that changes to existing policies are warranted. Deliberate changes that take into account the balance of interests among the different stakeholders can help preserve value across stakeholder groups and for society as a whole. Several options that offer long-term certainty to stakeholders were discussed in Section 4. However, immediate reforms to the way PV customers are compensated may not be needed in most jurisdictions at the levels of penetration in place today.

Balancing stakeholder interests and providing a stable environment where utilities, customers, and the solar industry can experience certainty can maximize value system-wide. 


\section{Glossary}

Net energy metering (NEM)

Net metering is a methodology under which electric energy generated by or on behalf of a PV customer and delivered to the electricity provider distribution facilities may be used to offset electric energy provided by the electricity provider to the PV customer during the applicable billing period (IREC 2009).

\section{Grandfathering}

A grandfathering provision excludes systems installed before a certain date (typically the date when the new rate becomes effective) from rate reform. The rate structure for grandfathered PV customers does not change for a period up to the life of the system.

\section{Distributed generation}

Electric generation systems interconnected to the distribution network.

\section{PV customer}

In this report, the term is used broadly to describe utility customer who owns a distributed PV system or other types of distributed generation system.

\section{Customer charges}

Fees that utility customers pay every month regardless of consumption, typically in the $\$ 5$ to $\$ 10$ range. Customer charges are meant to cover the costs of customer billing and collection.

\section{Fixed charges}

Charges that the utility includes in monthly electricity bills and that are assessed independently of consumption. Fixed charges are meant to recover the costs of customer billing and collection, and other costs that do not vary with consumption, such as distribution infrastructure capital and maintenance costs.

\section{Minimum bills}

A monthly charge assessed only in cases when customer consumption charges do not reach a minimum threshold. The difference with fixed charges is that minimum bills do not apply when monthly consumption charges do reach said threshold.

\section{Value of solar tariff}

An electric tariff meant to compensate distributed PV generators for avoided utility and environmental costs.

\section{Non-PV customer, non-participant ratepayer}

A utility customer who does not own a distributed generation system and therefore cannot participate on NEM programs.

\section{Investor-owned utility (IOU)}

A privately-owned, publicly traded electricity company that is regulated by a state regulatory body. 


\section{Renewable portfolio standard (RPS)}

RPSs require utilities to use or procure renewable energy or renewable energy credits (RECs) to account for a certain percentage of their retail electricity sales - or a certain amount of generating capacity - according to a specified schedule. (Renewable portfolio goals are similar to RPS policies, but goals are not legally binding.) The term "set-aside" or "carve-out" refers to a provision within an RPS that requires utilities to use a specific renewable resource (usually solar energy) to account for a certain percentage of their retail electricity sales (or a certain amount of generating capacity) according to a set schedule (DSIRE n.d.). 


\section{References}

ASU-EPIC (Arizona State University Energy Policy Innovation Council). 2013. “APS's Proposal to Change Net-Metering.” Tempe: Arizona State University. http://energypolicy.asu.edu/wp-content/uploads/2012/03/APS-Net-Metering-Brief-SheetDraft-_-Final.pdf.

Aznar, Alexandra. 2014. "Louisiana: Net Metering Cost/Benefit Study Authorized." NREL: Solar STAT Blog. August 21. https://www.nrel.gov/tech_deployment/state_local_governments/blog/vos-series_louisiana. Bhanot, Karan, and Carl Larsson. 2014. "'Uncovering' The Cost Of Regulatory Uncertainty." Paper presented at the European Finance Association 41st Annual Meeting, Lugano, Switzerland, August 27-30. https://www.conftool.com/efa2014/index.php/EFA_20141267-Bhanot$\% \mathrm{E} 2 \% 80 \% 9 \mathrm{CUncovering} \% \mathrm{E} 2 \% 80 \% 9 \mathrm{D} \_$The_Cost_Of_Regulatory_Uncertainty.pdf?page $=$ downloadPaper\&filename $=$ EFA_2014-1267-Bhanot-

$\% \mathrm{E} 2 \% 80 \% 9 \mathrm{CUncovering} \% \mathrm{E} 2 \% 80 \% 9 \mathrm{D} \_$The_Cost_Of_Regulatory_Uncertainty.pdf\&form id $=1267 \&$ form_version $=$ final.

Beach, R. Thomas, and Patrick G. McGuire. 2013. "Evaluating the Benefits and Costs of Net Energy Metering in California." Oakland, CA: Vote Solar. http://votesolar.org/wpcontent/uploads/2013/01/Crossborder-Energy-CA-Net-Metering-Cost-Benefit-Jan-2013final.pdf.

Bird, Lori, J. McLaren, J. Heeter, C. Linvill, J. Shenot, R. Sedano, and J. Migden-Ostrander. 2013. "Regulatory Considerations Associated with the Expanded Adoption of Distributed Solar." TP-6A20-60613. Golden, CO: National Renewable Energy Laboratory. http://www.nrel.gov/docs/fy14osti/60613.pdf.

Black \& Veatch. 2013. "Net Energy Metering: Fair Compensation for Clean Electricity or Unjust Subsidy?" Energy Strategies Report. http://bv.com/energy-strategies-report/june-2013issue/net-energy-metering-fair-compensation-for-clean-electricity-or-unjust-subsidy.

Bronski, Peter, Jon Creyts, Mark Crowdis, Stephen Doig, John Glassmire, Leia Guccione, Peter Lilienthal, et al. 2015. "The Economics of Load Defection.” Snowmass, CO: Rocky Mountain Institute. http://www.rmi.org/electricity_load_defection.

Brown, Ashley C. 2014. Joint Application of Wisconsin Electric Power Company and Wisconsin Gas LLC, both d/b/a WE Energies, to Conduct a Biennial Review of Costs and Rates - Test Year 2015 Rates (Rebuttal Testimony of Ashley C. Brown on behalf of Wisconsin Electric Power Company). Public Service Commission of Wisconsin.

Byrd, Stephen, Timothy Radcliff, Simon Lee, Bobby Chada, Dominik Olszewski, Yuka Matayoshi, Parag Gupta, et al. 2014. "Solar Power \& Energy Storage: Policy Factors vs. Improving Economics." New York: Morgan Stanley.

http://energystorage.org/system/files/resources/morgan_stanley_solar_power_energy_stora ge_blue_paper_july_29_2014.pdf.

Campbell, Becky, and Mike Taylor. 2014. "Utility Solar Market Trends Briefing." Washington, D.C.: Solar Electric Power Association.

Cardwell, Diane. 2013. "Compromise in Arizona Defers a Solar Power Fight." New York Times, November 15, sec. Business Day / Energy \& Environment. http://www.nytimes.com/2013/11/16/business/energy-environment/compromise-inarizona-defers-a-solar-power-fight.html. 
CMP (Central Maine Power). 2014. "Pricing Schedules." Central Maine Power. http://www.cmpco.com/YourHome/pricing/pricingSchedules/default.html.

Content, Thomas. 2014. "State Regulators Approve 83\% Increase in Green Bay Utility's Fixed Charge.” Milwaukee Journal Sentinel, November 6.

$\mathrm{http}$ ://www.jsonline.com/business/state-regulators-approve-83-in-green-bay-utilitys-fixedcharge-b99385986z1-281824701.html.

—. 2015. "Renewable Energy Advocates Win Court Case on Utility Solar Changes." Milwaukee Journal Sentinel, February 9.

http://www.jsonline.com/blogs/business/291297891.html.

Cornfeld, Josh, and Shayle Kann. 2014. "The Minimum Bill as a Net Energy Metering Solution, Examining the Massachusetts Example.” Boston: GTM Research.

CPUC (California Public Utilities Commission). 2013. "California Net Energy Metering Ratepayer Impacts Evaluation.” San Francisco: California Public Utilities Commission. http://www.cpuc.ca.gov/NR/rdonlyres/75573B69-D5C8-45D3-BE223074EAB16D87/0/NEMReport.pdf.

CUNY (The City University of New York). 2015. "NYS Net Metering." The City University of New York. Accessed July 10.

http://www.cuny.edu/about/resources/sustainability/nyssolar/NYSNetMeteringAnalysis.ht $\mathrm{ml}$.

Davis, Richie. 2014. "Compromise Solar 'net Metering' Bill OK'd.” The Recorder, August 1. http://www.recorder.com/home/12980449-95/compromise-solar-net-metering-bill-okd.

DOE (U.S. Department of Energy). n.d. "Reducing Non-Hardware Costs." DOE (U.S. Department of Energy). http://energy.gov/eere/sunshot/reducing-non-hardware-costs.

_ 2015. "Renewable Energy Certificates (RECs)." Green Power Markets. April 3. http://apps3.eere.energy.gov/greenpower/markets/certificates.shtml?page $=5$.

DSIRE (Database of State Incentives for Renewables \& Efficiency). 2015. "Database of State Incentives for Renewables and Efficiency - Glossary." DSIRE (Database of State Incentives for Renewables \& Efficiency). Accessed July 15. $\mathrm{http}: / /$ www.dsireusa.org/glossary/.

Duke Energy. 2015. "North Carolina Solar Distributed Generation.” Duke Energy. Accessed July 15. http://www.duke-energy.com/north-carolina/renewable-energy/nc-solardistributed-generation-program.asp.

Durkay, Jocelyn. 2014. "Net Metering: Policy Overview and State Legislative Updates." National Conference of State Legislatures. December 18. http://www.ncsl.org/research/energy/net-metering-policy-overview-and-state-legislativeupdates.aspx.

Edge, Ryan, Mike Taylor, Nadav Enbar, and Lindsey Rogers. 2014. "Utility Strategies for Influencing the Locational Deployment of Distributed Solar - Executive Summary." Washington, D.C.: Solar Electric Power Association.

http://www.solarelectricpower.org/discover-resources/publications-and-media.aspx.

EIA (U.S. Energy Information Administration). 2012. "Participation in Electric Net-Metering Programs Increased Sharply in Recent Years." Today In Energy. May 15. http://www.eia.gov/todayinenergy/detail.cfm?id=6270.

- 2014. "Table 5.6.A. Average Retail Price of Electricity to Ultimate Customers by EndUse Sector, by State, August 2014 and 2013 (Cents per Kilowatthour).” Electric Power 
Monthly, August 26.

http://www.eia.gov/electricity/monthly/epm_table_grapher.cfm?t=epmt_5_6_a.

. 2015a. "Electric Power Annual 2013." http://www.eia.gov/electricity/annual/.

. 2015b. "Electric Power Sales, Revenue, and Energy Efficiency Form EIA-861 Detailed

Data Files." August 11. http://www.eia.gov/electricity/data/eia861/.

Energy and Environmental Economics Inc (E3). 2014. "Nevada Net Energy Metering Impacts

Evaluation."

http://puc.nv.gov/uploadedFiles/pucnvgov/Content/About/Media_Outreach/Announcement

s/Announcements/E3 PUCN NEM Report 2014.pdf?pdf=Net-Metering-Study.

EPRI (Electric Power Research Institute). 2014a. "The Integrated Grid. Realizing the Full Value of Central and Distributed Energy Resources."

http://www.epri.com/abstracts/Pages/ProductAbstract.aspx?ProductId=0000000030020027 33.

. 2014. "The Integrated Grid: Phase II. Development of a Cost-Benefit Framework." Palo Alto, CA: Electric Power Research Institute.

http://www.epri.com/abstracts/Pages/ProductAbstract.aspx?ProductId=0000000030020040 28.

EQ Research. 2014. “CA: Turlock Irrigation District Caps Net Metering at 5\%.” EQ Research Blog. September 25. http://eq-research.com/blog/ca-turlock-irrigation-district-caps-nemprogram-at-5/.

- 2015. "OK: OG\&E Files to Zap DG Customers with Surcharges." EQ Research Blog. August 17. http://eq-research.com/blog/ok-oge-files-to-zap-dg-customers-with-surcharges/.

Evans-Brown, Sam. 2015. "As Kearsarge Solar Campaign Nears Deadline, Limit On Incentives

Causes Uncertainty.” New Hampshire Public Radio. http://nhpr.org/post/kearsarge-solarcampaign-nears-deadline-limit-incentives-causes-uncertainty.

Fabrizio, Kira R. 2013. "The Effect of Regulatory Uncertainty on Investment: Evidence from Renewable Energy Generation." Journal of Law, Economics, and Organization, August. doi:10.1093/jleo/ews007.

Farrell, John. 2014. “Minnesota's Value of Solar, Can a Northern State's New Solar Policy Defuse Distributed Generation Battles?" Washington, D.C.: Institute for Local Self-

Reliance. http://www.ilsr.org/wp-content/uploads/2014/04/MN-Value-of-Solar-fromILSR.pdf.

Faruqui, Ahmad. 2014. "The Emergence of the Energy Services Utility." presented at the North Carolina Electric Membership Corporation Statewide Board Retreat, June 5.

http://www.brattle.com/system/publications/pdfs/000/005/015/original/The_Emergence_of the_Energy_Services_Utility.pdf?1402325928.

Felder, Frank A., and Colin J. Loxley. 2013. "The Implications of a Vertical Demand Curve in Solar Renewable Portfolio Standards." New Brunswick, NJ: Rutgers Univeristy. http://ceep.rutgers.edu/wp-content/uploads/2013/11/VerticalDemandCurve.pdf.

Feldman, David, Galen Barbose, Robert Margolis, Ted James, Samantha Weaver, Naim Darghouth, Ran Fu, Carolyn Davidson, Sam Booth, and Ryan Wiser. 2014. "Photovoltaic System Pricing Trends: Historical, Recent, and Near-Term Projections. 2014 Edition." September 22. http://www.nrel.gov/docs/fy14osti/62558.pdf.

Fitch Ratings. 2013. "Running Backwards: Net Metering Short Circuits Electric Sales." London: Fitch Ratings. http://s3.amazonaws.com/dive_static/diveimages/Fitch_Net_Metering_Dec_2013.pdf. 
Fox-Penner, Peter S. 2014. Smart Power: Climate Change, the Smart Grid, and the Future of Electric Utilities. Washington, D.C.: Island Press.

Gibson, Scott. 2014. "Maine Utility Seeks Surcharge for Renewables." Green Building News. March 14. http://www.greenbuildingadvisor.com/blogs/dept/green-building-news/maineutility-seeks-surcharge-renewables.

Gilleo, Annie, Marty Kushler, Maggie Molina, and Dan York. 2015. "Valuing Efficiency: A Review of Lost Revenue Adjustment Mechanisms." Research Report U1503. Washington, D.C.: American Council for an Energy-Efficient Economy. http://aceee.org/valuingefficiency-review-lost-revenue-adjustment.

Gordon, Kenneth, and Wayne P. Olson. 2004. "Retail Cost Recovery and Rate Design in a Restructured Environment.” Washington, D.C.: Edision Electric Institute. http://www.hks.harvard.edu/hepg/Papers/Gordon.Olson.Retail.Cost.Recovery.pdf.

Hand, Mark. 2015. "Essential Rate Tool or Blunt Instrument? Debate Intensifies on Fixed Charges." SNL. July 1. https://www1.snl.com/InteractiveX/Article.aspx?cdid=A-3306644412847.

Haynes, Rusty. 2015. "NEM Legislation.” Email to author.

Heeter, Jenny, Lori Bird, and Rachel Gelman. 2014. "Status of Net Metering: Assessing the Potential to Reach Program Caps." TP-6420-61858. Golden, CO: National Renewable Energy Laboratory. http://www.nrel.gov/docs/fy14osti/61858.pdf.

Hines, Kayci G. 2015. "Solar Shift: An Analysis of the Federal Income Tax Issues Associated with the Residential Value of Solar Tariff." Arizona Journal of Environmental Law and Policy 5: 388-97.

Hledik, Ryan. 2014. "Rediscovering Residential Demand Charges.” The Electricity Journal 27 (7): 82-96. doi:10.1016/j.tej.2014.07.003.

Howland, Ethan. 2013. "What SolarCity's Landmark Financing Deal Means for Utilities." Utility Dive. November 25. http://www.utilitydive.com/news/what-solarcitys-landmark-financingdeal-means-for-utilities/198598/.

Hyde, Karen T. 2013. In The Matter of the Application of Public Service Company of Colorado for Approval of Its 2014 Renewable Energy Standard Compliance Plan (Direct Testimony and Exhibit of Karen T. Hyde). Colorado Public Utilities Commission.

IEA (International Energy Agency). 2014. "Renewable Energy Medium-Term Market Report 2014, Executive Summary." Paris: International Energy Agency. http://www.iea.org/Textbase/npsum/MTrenew2014SUM.pdf.

Indiana Energy Association. 2015. "Energy Efficiency: Lost Revenues and Financial Incentives." Fort Wayne: Indiana Michigan Power.

https://www.indianamichiganpower.com/global/utilities/lib/docs/info/projects/IntegratedRe sourcePlan/lostrevfinincent-03162015.pdf.

Inskeep, Benjamin, Heather Calderwood, Ethan Case, Kate Daniel, Brian Lips, Autumn Proudlove, Achyut Shrestha, Kathryn Wright, Ryan Cook, and Chad Laurent. 2015. "The 50 States of Solar, Q2 2015.” Raleigh, NC: NC Clean Energy Technology Center. http://www.mc-group.com/the-50-states-of-solar-net-metering-quarterly-update/.

IREC (Interstate Renewable Energy Council). 2009. “Net Metering Model Rules.” Latham, NY: Interstate Renewable Energy Council. http://irecusa.org/fileadmin/user_upload/ConnectDocs/IREC_NM_Model_October_20091.pdf. 
Kauffman, K. 2015. “Arizona’s Utility-Owned Solar Programs: New Price Models, Grid Integration and Collaboration." Utility Solar Blog - Solar Electric Power Association. January 8. http://www.solarelectricpower.org/utility-solar-blog/2015/january/arizonasutility-owned-solar-programs-new-price-models,-grid-integration-and-collaboration.aspx.

Kennerly, Jim, Kathryn Wright, Chad Laurent, Wilson Rickerson, and Autumn Proudlove. 2014. "Rethinking Standby \& Fixed Cost Charges: Regulatory \& Rate Design Pathways to Deeper Solar PV Cost Reductions.” Raleigh: North Carolina State University. http://nccleantech.ncsu.edu/wp-content/uploads/Rethinking-Standby-and-Fixed-CostCharges_V2.pdf.

Kind, Peter. 2013. "Disruptive Challenges: Financial Implications and Strategic Responses to a Changing Retail Electric Business." Washington, D.C.: Edison Electric Institute. http://www.eei.org/ourissues/finance/documents/disruptivechallenges.pdf.

Lazar, Jim. 2014. "Electric Utility Residential Customer Charges and Minimum Bills: Alternative Approaches for Recovering Basic Distribution Costs.” Montpelier, VT: Regulatory Assistance Project. http://www.raponline.org/document/download/id/7361.

Lazar, Jim, Frederick Weston, and Wayne Shirley. 2011. "Revenue Regulation and Decoupling: A Guide to Theory and Application." Montpelier, VT: Regulatory Assistance Project. http://www.raponline.org/docs/RAP_RevenueRegulationandDecoupling_2011_04.pdf.

Lehr, Ronald. 2013. "Utility and Regulatory Models for the Modern Era." San Francisco: America's Power Plan. http://americaspowerplan.com/site/wpcontent/uploads/2013/10/APP-UTILITIES.pdf.

Lillian, Jessica. 2011. “Dominion's New Fees: Rightful Cost Recovery Or An Unfair Attack On PV?" Solar Industry Magazine, December 6. http://www.solarindustrymag.com/e107_plugins/content/content.php?content.9266.

Lowder, Travis, and Michael Mendelsohn. 2013. "The Potential of Securitization in Solar PV Finance.” TP-6A20-60230. Golden, CO: National Renewable Energy Laboratory. http://www.nrel.gov/docs/fy14osti/60230.pdf.

Makyhoun, Miriam, Mike Taylor, and Sara Clark. 2014. "Utility Solar Market Snapshot, Solar Market Comes of Age in 2013." Washington, D.C.: Solar Electric Power Association. https://www.solarelectricpower.org/media/180658/solar-market-snapshot-ver8.pdf.

Martin, Christopher. 2013. "Arizona Approves Grid-Connection Fees for Solar Rooftops." Bloomberg, November 15. http://www.bloomberg.com/news/2013-11-15/arizonaregulators-impose-power-grid-fees-for-solar-roofs.html.

MassACA (Massachusetts System of Assurance of Net Metering Eligibility). 2015. "Provisional Application Activity and Remaining Capacity." Boston: Massachusetts System of Assurance of Net Metering Eligibility. https://app.massaca.org/allocationreport/report.aspx\#Pd289d03f9f7d41d78405240801b22f 37_3_oHit0.

Mendelsohn, Michael, and David Feldman. 2013. "Financing U.S. Renewable Energy Projects Through Public Capital Vehicles: Qualitative and Quantitative Benefits.” TP-6A20-58315. Golden, CO: National Renewable Energy Laboratory. http://www.nrel.gov/docs/fy13osti/58315.pdf.

Minnesota Department of Commerce. 2014. "Value of Solar Tariff Methodology." http://mn.gov/commerce/energy/topics/resources/energy-legislation-initiatives/value-ofsolar-tariff-methodology\%20.jsp. 
Minnesota Office of the Revisor of Statutes. 2013. 88th Legislature. 2013 Regular Session. Ch. 85--H.F.No. 729.

https://www.revisor.leg.state.mn.us/laws/?year=2013\&type $=0 \&$ doctype $=$ Chapter\&id $=85 \&$ format $=$ pdf.

Norris, Benjamin L., Morgan C. Putnam, and Thomas E. Hoff. 2014. "Minnesota Value of Solar: Methodology." Saint Paul: Minnesota Department of Commerce.

http://www.growsolar.org/wp-content/uploads/2014/10/MN-Value-of-SolarMethodolgy.pdf.

NYDPS (New York Department of Public Service). 2014. "Reforming the Energy Vision, NYS Department of Public Service Staff Report and Proposal.” Case 14-M-0101. Albany: New York Public Service Commission.

http://www3.dps.ny.gov/W/PSCWeb.nsf/96f0fec0b45a3c6485257688006a701a/26be8a939 67e604785257cc40066b91a/\$FILE/ATTK0J3L.pdf/Reforming\%20The\%20Energy\%20Vis ion\%20(REV)\%20REPORT\%204.25.\%2014.pdf.

Overcast, H. Edwin. 2015. "Black \& Veatch: Why Fixed Charges Are a Solution to the Solar Conundrum." Utility Dive. March 10. http://www.utilitydive.com/news/black-veatch-whyfixed-charges-are-a-solution-to-the-solar-conundrum/372539/.

Passera, Laurel. 2011. "Virginia SCC Approves Controversial Net Metering Standby Fee." Interstate Renewable Energy Council. IREC Regulatory Reform News. December 7. http://www.irecusa.org/2011/12/virginia-scc-approves-controversial-net-metering-standbyfee/.

Paulman, Ken. 2014. "If 'value of Solar' Is Optional, Will Minnesota Utilities Adopt It?." Midwest Energy News, April 9. http://www.midwestenergynews.com/2014/04/09/if-valueof-solar-is-optional-will-minnesota-utilities-adopt-it/.

Pentland, William. 2014. "Why the Net Metering Fight Is a Red Herring for Utilities." Utility

Dive. September 11. http://www.utilitydive.com/news/why-the-net-metering-fight-is-a-redherring-for-utilities/307061/.

PSE\&G (Public Service Electric and Gas). 2015. "PSEG, New Jersey's Largest Electricity Provider, Is a Leading Source of Solar Development in the United States." Public Service Electric and Gas. https://www.pseg.com/info/media/solar/index.jsp.

Public Utility Commission of Oregon. 2014. "Investigation into the Effectiveness of Solar Programs in Oregon." Salem: Public Utility Commission of Oregon.

PwC. 2013. "Solar Securitization: A Promising Financing Opportunity for Solar Developers." San Jose: PwC. http://www.pwc.com/en_US/us/technology/publications/cleantechperspectives/pdfs/pwc-cleantech-perspectives-solar-securitization.pdf.

Rábago, Karl R. 2013. “The 'Value Of Solar' Rate: Designing An Improved Residential Solar Tariff.” Solar Industry Magazine.

http://www.solarindustrymag.com/issues/SI1302/FEAT_04_The\%20Value\%200f\%20Sola r.html.

RENEW Wisconsin. 2014. "Alliant 2014 Net Metering Changes.” RENEW Wisconsin. http://www.renewwisconsin.org/action/Alliantcase.html.

RMI (Rocky Mountain Institute). 2013. "A Review of Solar PV Benefit \& Cost Studies, 2nd Edition.” Boulder, CO: Rocky Mountain Institute. http://www.rmi.org/cms/Download.aspx?id=10793\&file=eLab_DERBenefitCostDeck_2nd Edition\&title $=\mathrm{A}+$ Review + of + Solar + PV + Benefit+and + Cost + Studies. 
Roberts, Casey. 2015. "Fighting Back Against High Fixed Charges on Electricity Bills." The Planet, Sierra Club. January 27. http://www.sierraclub.org/planet/2015/01/fighting-backagainst-high-fixed-charges-electricity-bills.

Satchwell, Andrew, Peter Cappers, and Charles A. Goldman. 2011. "Carrots and Sticks: A Comprehensive Business Model for the Successful Achievement of Energy Efficiency Resource Standards.” In . Giens, France. http://emp.lbl.gov/publications/carrots-and-stickscomprehensive-business-model-successful-achievement-energy-efficienc.

Satchwell, Andrew, Andrew D. Mills, Galen L. Barbose, Ryan H. Wiser, Peter Cappers, and Naïm Darghouth. 2014. "Financial Impacts of Net-Metered PV on Utilities and Ratepayers: A Scoping Study of Two Prototypical U.S. Utilities.” LBNL-6913E. Berkeley, CA: Lawrence Berkeley National Laboratory. http:/emp.lbl.gov/publications/financial-impactsnet-metered-pv-utilities-and-ratepayers-scoping-study-two-prototypica.

SEIA (Solar Energy Industries Association), and GTM Research. 2014. "2013 U.S. Solar Market Insight Report.” Washington, D.C.: Solar Energy Industries Association.

SEPA (Solar Electric Power Association). 2015. "Utility Solar Business Models." Solar Electric Power Assocation. Accessed August 15. https://www.solarelectricpower.org/usbm-solardata-and-mapping.

Smith, Noah. 2015. "Clean Energy Revolution Is Ahead of Schedule.” BloombergView, April 8. http://www.bloombergview.com/articles/2015-04-08/clean-energy-revolution-is-wayahead-of-schedule.

SolarCity. 2014. "Form 10-K." United States Securities and Exchange Commission. http://apps.shareholder.com/sec/viewerContent.aspx?companyid=AMDA14LQRE\&docid=9864243.

Solar Industry Magazine Staff. 2013. "Idaho Power Seeks To Raise Solar Net-Metering Fees." Solar Industry Magazine, January 18.

http://solarindustrymag.com/e107_plugins/content/content.php?content.11936.

South Carolina Office of Regulatory Staff. 2014. Petition of the Office of Regulatory Staff to Establish Generic Proceeding Pursuant to the Distributed Energy Resource Program Act, Settlement Agreement. Public Service Commission of South Carolina.

S\&P (Standard \& Poor's). 2013. "Presale: SolarCity LMC Series I LLC (Series 2013-1)." RatingsDirect. New York: McGraw Hill Financial.

Stanton, Elizabeth A., Joseph Daniel, Tommy Vitolo, Pat Knight, David White, and Geoff Keith. 2014. "Net Metering in Mississippi: Costs, Benefits, and Policy Considerations."

Cambridge, MA: Synapse Energy Economics, Inc. http://www.synapseenergy.com/sites/default/files/Net\%20Metering\%20in\%20Mississippi.pdf.

Steward, Joelle R. 2014. Direct Testimony of Joelle R. Steward. Public Service Commission of Utah.

Swartz, Kristi E. 2014. "Can S.C.'s Groundbreaking Net Metering Policy Spread in the Southeast?” Energy Wire, December 16. http://www.eenews.net/stories/1060010601.

Taylor, Mike, Joyce McLaren, Karlynn Cory, Ted Davidovich, John Sterling, and Miriam Makhyoun. 2015. "Value of Solar: Program Design and Implementation Considerations." TP-6A20-62361. Golden, CO: National Renewable Energy Laboratory. http://www.nrel.gov/docs/fy15osti/62361.pdf.

Tomich, Jeffrey. 2014. "Minn. Case Puts Value of Solar in Spotlight.” Energy Wire, August 6. http://www.eenews.net/stories/1060004122. 
Trabish, Herman K. 2014. "IRS to Investigate Value of Solar Tariffs." Utility Dive. September 25. http://www.utilitydive.com/news/irs-to-investigate-value-of-solar-tariffs/313789/. . 2015. "Why SRP's Controversial Demand Charge Unlocks a Huge Opportunity for Solar-plus-Storage." Utility Dive. March 12. http://www.utilitydive.com/news/why-srpscontroversial-demand-charge-unlocks-a-huge-opportunity-for-solar-/372548/.

VPSD (Vermont Public Service Department). 2013. "Evaluation of Net Metering in Vermont Conducted Pursuant to Act 125 of 2012." Montpelier: Vermont Public Service Department. http://www.leg.state.vt.us/reports/2013ExternalReports/285580.pdf.

Walton, Robert. 2015. "Kentucky Utilities Drop Fixed Charge Increase Proposal in Rate Case Settlement." Utility Dive. April 24. http://www.utilitydive.com/news/kentucky-utilitiesdrop-fixed-charge-increase-proposal-in-rate-case-settlem/390268/.

Wan, Yih-huei, and H. James Green. 1998. "Current Experience With Net Metering Programs." In . Bakersfield, CA. http://apps3.eere.energy.gov/greenpower/resources/pdfs/current_nm.pdf.

Washington Electric Coop. 2014. "Net Metering." Washington Electric Coop. http://www.washingtonelectric.coop/net-metering/.

White, Kaiba. Undated. "Austin's Solar Tool Box: Value of Solar, Community Solar and Solar Leasing." http://www.solaraustin.org/wp-content/uploads/Solar-Programs.pdf.

WPS (Wisconsin Public Service). 2014. "2015 Rate Case Overview." Wisconsin Public Service. http://www.wisconsinpublicservice.com/company/investing/cost.aspx.

Xcel Energy. 2014. "Comments, In the Matter of Establishing a Distributed Solar Value Methodology under Minn. Stat. 216b.164, Subd. 10 (e) and (f), Docket No. E999/M-1465.” Xcel Energy. 


\section{Bibliography}

\section{Existing Policies by State}

Freeing the Grid. "Freeing the Grid: Best Practices in State Net Metering Policies and Interconnection Procedures." 2015. www.freeingthegrid.org.

This website includes links to statutes and commission orders

\section{Update on Recent Legislative and Regulatory Activity Nationwide}

Durkay, Jocelyn. "Net Metering: Policy Overview and State Legislative Updates." Denver: National Conference of State Legislatures, 2014. http://www.ncsl.org/research/energy/net-metering-policy-overview-and-statelegislative-updates.aspx.

This periodically updated page details net metering legislative updates from around the country.

Kennerly, Jim, Kathryn Wright, Chad Laurent, Wilson Rickerson, and Autumn Proudlove. Rethinking Standby \& Fixed Cost Charges: Regulatory \& Rate Design Pathways to Deeper Solar PV Cost Reductions. Raleigh: NC Clean Energy Technology Center, 2014. http://nccleantech.ncsu.edu/wp-content/uploads/Rethinking-Standby-and-FixedCost-Charges_V2.pdf.

Section 8 (Appendix) discusses the current (as of 2014) status of standby and fixed cost charge debates.

\section{Utility Strategies for an Environment of Increased Distributed Generation and Energy Efficiency}

Bird, L., J. McLaren, J. Heeter, C. Linvill, J. Shenot, R. Sedano, and J. Migden-Ostrander. Regulatory Considerations Associated with the Expanded Adoption of Distributed Solar. Golden, CO: National Renewable Energy Laboratory, 2013. http://www.nrel.gov/docs/fy14osti/60613.pdf. Informed by the discussion among utilities, regulators, and solar industry stakeholders, this report examines considerations for regulators associated with expanded adoption of distributed PV.

Satchwell, Andrew, Peter Cappers, and Charles A. Goldman. "Carrots and Sticks: A Comprehensive Business Model for the Successful Achievement of Energy Efficiency Resource Standards." LBNL-4399E. Paper presented at ECEEE Summer Study, Giens, France, June 6-11, 2011. http://emp.lbl.gov/sites/all/files/lbnl-4399e 0.pdf. This paper analyzes the financial impacts of an energy efficiency resource standard on a large electric utility in Arizona using a pro-forma utility financial model.

\section{Alternative Utility Regulatory and Business Models}

Energy Industry Working Group. Creating a 21st Century Electricity System for New York State.

Washington, D.C.: Advanced Energy Economy, 2014. http://cdn2.hubspot.net/hub/211732/file-549007301pdf/PDF/Creating_a 21stCenturyElectricitySystem_for_NewYorkState.pdf?t=14114827 $\underline{76568 .}$. 
This document summarizes the work, conducted over a three-month period, by an informal electric industry working group facilitated by Advanced Energy Economy.

Lehr, Ronald. New Utility Business Models: Utility and Regulatory Models for the Modern Era. America's Power Plan. San Francisco: America's Power Plan, 2013. http://americaspowerplan.com/wp-content/uploads/2013/10/APP-UTILITIES.pdf. This document outlines three new regulatory options for new utility business models.

Rocky Mountain Institute. New Business Models for the Distribution Edge: The Transition from Value Chain to Value Constellation. Boulder, CO: Rocky Mountain Institute, 2013. http://www.rmi.org/new business models. This paper describes how and why the forces changing the electricity system challenge existing pricing and business models, principles that should guide the creation of new business models, and the emerging "solution set" of new business models. 


\section{Appendix. PVWatts Simulation Parameters}

The PVWatts ${ }^{\circledR}$ (http://pvwatts.nrel.gov/) online tool was used to simulate a $6 \mathrm{~kW}$ system installed in the territory of each utility in Table A-1. Annual PV production is the result of the total yearly output in $\mathrm{kWh}$, times the energy rate. Source for energy rates are Genability, OpenEI Utility Rate Database, documents filed in the relevant public utility commission dockets, and the utility websites.

\section{Table A-1. PVWatts Simulation Parameters}

\begin{tabular}{|c|c|c|c|c|c|c|c|c|c|c|c|}
\hline & & & & Pro & osed Ch & rges (De & as) & & & & \\
\hline Utility & State & Status & 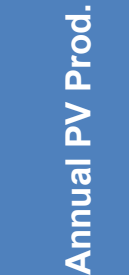 & 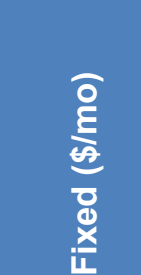 & 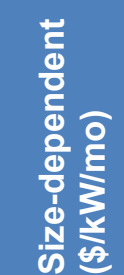 & 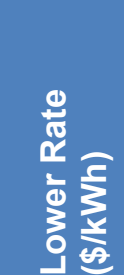 & 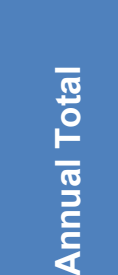 & 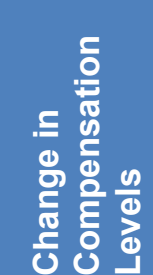 & $\begin{array}{l}\text { PVWatts } \\
\text { Location }\end{array}$ & $\begin{array}{l}\frac{1}{3} \\
\frac{1}{3} \\
\frac{2}{3} \\
0 \\
3 \\
3\end{array}$ & $\begin{array}{l}\text { Energy } \\
\text { Rate }\end{array}$ \\
\hline Idaho Power & ID & Denied & $\$ 778$ & $-\$ 15.92$ & $-\$ 1.48$ & $-\$ 0.02$ & $-\$ 503$ & $-64.7 \%$ & Boise, ID & 8,645 & $\$ 0.09$ \\
\hline Xcel Energy & $\mathrm{CO}$ & $\begin{array}{l}\text { Separate } \\
\text { Docket }\end{array}$ & $\$ 952$ & & & $-\$ 0.06$ & $-\$ 535$ & $-56.2 \%$ & Boulder, CO & 9,066 & $\$ 0.11$ \\
\hline $\begin{array}{l}\text { Wisconsin } \\
\text { Public Service } \\
\text { Corp }\end{array}$ & WI & Approved & $\$ 994$ & $-\$ 9.00$ & & $-\$ 0.01$ & $-\$ 174$ & $-17.5 \%$ & Green Bay, WI & 7,645 & $\$ 0.13$ \\
\hline $\begin{array}{l}\text { Central Maine } \\
\text { Power }\end{array}$ & ME & $\begin{array}{l}\text { closed, } \$ 10.65 \\
\text { FC for all res }\end{array}$ & $\$ 1,109$ & $-\$ 15.47$ & & & $-\$ 186$ & $-16.7 \%$ & Augusta, ME & 7,987 & $\$ 0.14$ \\
\hline $\begin{array}{l}\text { Arizona Public } \\
\text { Service }\end{array}$ & $A Z$ & $\begin{array}{l}\text { Approved as } \\
\text { amended }\end{array}$ & $\$ 1,226$ & & $-\$ 0.70$ & & $-\$ 50$ & $-4.1 \%$ & Phoenix, AZ & 1,0220 & $\$ 0.12$ \\
\hline
\end{tabular}

